\title{
Strategic behavior within families of hedge funds ${ }^{\diamond}$
}

\author{
Olga Kolokolova a,* \\ ${ }^{a}$ University of Manchester, Manchester Business School, Manchester, M15 6PB, UK
}

This version: October 29, 2010

\begin{abstract}
The paper investigates the strategic behavior of hedge fund families. It focuses on decisions to start and liquidate family-member funds. Hedge fund families tend to liquidate funds that underperform compared to other member funds, and to replace them by new ones. By choosing a launch time after a short period of superior performance by their member funds, families extend the spillover to new funds. Hedge fund families seem to be more experienced in promoting their funds and attracting fund inflow than in generating superior performance. This results in higher dollar compensation earned by managers within multifund families than in stand-alone funds.
\end{abstract}

JEL classification: G23; G11

Keywords: Hedge fund families; Investment companies; Fund liquidation; Fund origination

\footnotetext{
-A previous version of this paper circulated under the title "Birth and death of family hedge funds: The determinants". While working on the paper, the author was affiliated with the University of Konstanz. The author thanks Andrea Buraschi, Robert Kosowski, Mark Schindler, and seminar participants at Imperial College Business School, the Swiss Banking Institute, University of Zurich, and an anonymous referee, for helpful comments.

* Corresponding author. Tel.: +44 161306 2081; fax: +44 1612754023.

E-mail address: olga.kolokolova@mbs.ac.uk (O. Kolokolova)
} 


\section{Introduction}

The number of hedge funds and the assets under their management has grown exponentially during the last decade, and has accordingly attracted increasing attention from researchers. Historically, individual hedge funds have been treated as independent investment vehicles with strategies determined solely by their portfolio managers. Individual hedge funds, however, are not always independent of each other, but may be controlled by the same investment company, taking the form of a family ${ }^{1}$ of funds. According to the ALTVEST database used in this study, some $70 \%$ of all hedge funds belong to such families. For these funds, long-term decisions such as fund origination, liquidation, closure to further investments, fund promotion and fund marketing (by listing in commercial hedge fund databases) can be made strategically by these over-arching investment companies.

Hedge fund investors, however, are considered to be sophisticated. It should be relatively difficult to manipulate their beliefs about family quality and future hedge fund profitability via any kind of strategic behavior by investment companies. Thus the empirical results of this paper are surprising, and indicate that hedge fund companies do behave strategically, and that this behavior is financially beneficial for their managers.

Although the strategic behavior of hedge fund families has not been extensively studied in the literature, there is abundant evidence concerning the strategic behavior of mutual fund families. See, e.g., Khorana and Servaes (1999) for origination decisions, Zhao (2004) for decisions to close funds for investments, Nanda, Wang and Zheng (2004) for strategic fund promotion, and Gaspar, Massa and Matos (2006) for cross-fund subsidization. This paper concentrates on two major decisions by hedge fund families - fund origination and fund liquidation - since these primarily affect the opportunity set of investors. The analysis of other family-related decisions is postponed for future research.

\footnotetext{
${ }^{1}$ The terms "family" and "investment company" will be used interchangeably throughout this paper.
} 
Decisions concerning the founding of new hedge funds have not received much attention in the existing literature. I am aware of only one paper, Boyson (2008), in which the performance difference between funds from large and small families is addressed. The author tries to relate the decision to originate a hedge fund to the increasing market share of the company.

Hedge fund survival, on the contrary, has been extensively studied in the literature (see Liang (2000), Gregoriou (2002), and Park (2006)). The authors relate the probability of a hedge fund's liquidation to its performance and risk, and to different organizational factors, such as incentive fees and lockup periods. Alas, this research seems to disregard the fact that liquidation decisions may be taken strategically by investment companies operating several funds; and, moreover, that they can be linked to the origination decision.

This paper fills this gap and inspects more closely the determinants of the birth and death of family held hedge funds, while accounting for the possible strategic decisions by investment companies. The empirical evidence suggests that investment companies tend to liquidate funds that underperform relative to the company average. By doing so, they not only improve the average family performance, but also ensure that only those funds that are able to generate high fee income operate within the family. Hedge funds with fewer assets under management, lower fees, and lower value relative to the high-water mark than the family average are more likely to be liquidated. At the same time, investment companies do not simply liquidate the black sheep of the family; they also tend to replace poorly performing funds with new ones.

Trying to capitalize on the good past performance of family-member funds, investment companies are more likely to start new funds when other member funds perform well. Notably, the families choose the fund launch time strategically, after a short period of superior performance by other family-member funds. Investment companies seem to 
optimize the launch time to encourage a money inflow to the new funds. The launching decision in itself should thus not be interpreted as a signal of outstanding family quality that will persist in the future.

Additionally, I find evidence of the presence of economies of scale in hedge fund families, similar to mutual fund families. Larger families, and families that have opened funds in the past, are more likely to start new ones. At the same time, hedge fund families appear to be much more specialized than mutual fund families, and the probability of starting a new fund with a particular style increases with the number of funds with the same style already launched within the family.

Altogether, hedge fund families seem to manipulate their funds strategically, to improve the average performance record. I document the existence of the spillover effect in hedge fund families, which provides an additional incentive for such behavior: capital inflow into newly originated funds within fund families increases with the past performance of other family-member funds.

The spillover to new funds within investment companies, in conjunction with investors' preference for "familiar" (already existing) companies, leads to higher inflows to new hedge funds launched within already existing companies than to funds launched as stand-alone vehicles. Remarkably, investors do not seem to be aware of the potential strategic choice of the exact time of a hedge fund start. Flows to new funds are not sensitive to the possible timing of the fund launch. They react positively to the short-term outperformance of other family-member funds, even if they do not perform persistently well.

Hedge fund families seem to be more successful in promoting their funds and attracting higher fund inflow than in generating superior performance. Hedge funds from multi-fund families are on average twice as large as their peers from single-fund families, but they deliver significantly lower returns. Their managers earn higher monetary compensation from 
management fees. Despite lower returns, the dollar incentive fees earned by the fund managers of newly launched funds within multi-fund companies are also higher than those earned by managers within single-fund companies. The lower returns are more than offset by the greater amount of assets under management.

The paper proceeds as follows: The main testable hypotheses are developed in Section 2. The methodological approach and the control variables are discussed in Section 3. Section 4 describes the data. Section 5 presents the empirical results. Some extensions and robustness are discussed in Section 6, and the last section concludes.

\section{Hypotheses development}

\subsection{Liquidation of hedge funds within fund families}

Investment companies receive profits (fee income) from existing hedge funds. The total income includes both the management fee income, which is proportional to the assets under management, and the incentive fee income, which depends on the cumulative fund return, and its value relative to the high-water mark.

In maximizing management fee income, investment companies are interested in higher capital inflows to their funds. Intuitively it should be much easier to attract investors into a fund if other funds within the family perform well. There is some evidence for mutual funds that the good performance of one fund within a family attracts higher inflow to other funds within the same family (Nanda, Wang and Zheng (2004)). Similar effects can provide hedge fund investment companies with incentives to improve the average performance record of the family.

According to Massa (2003), mutual fund investors first pick a fund family, and then an individual fund in which to invest. If the decision making process of hedge fund investors is similar, hedge fund families have additional incentives to improve the average family quality 
by liquidating poorly performing funds, and keeping only those with high returns, which are able to attract new investors and to earn high management and incentive fees. The relative position of a hedge fund within its family should have a significant influence on the probability of the fund's liquidation.

Hypothesis 1: The relative characteristics of a hedge fund within its family are more valuable liquidation predictors than their absolute counterparts.

The crucial factors for hedge fund liquidation decisions are those that contribute to a general positive perception of the family by market participants, and those that influence the management and incentive fee income of the company. These factors include hedge fund average return and risk (Liang (2000), Brown, Goetzmann and Park (2001)), assets under management (Getmansky (2005)), managers' incentives and flexibility (Ackermann, McEnally and Ravenscraft (1999)), and the value relative to the high-water mark (Hodder and Jackwerth (2007)). I expect to find that hedge funds having higher than average returns, lower risk, larger assets under management, larger percentage flows, higher management and incentive fees, longer notice period prior to redemption, longer lockup periods, and higher value relative to the high-water mark than other funds within the same investment company are less likely to be liquidated.

\subsection{Origination of new hedge funds within fund families}

Having decided to liquidate a hedge fund, a company commits to redeem the shares of the investors. Consequently, it loses the associated management fee income. Hedge funds, however, are often liquidated when they are below the high-water mark. Such hedge funds have low potential to earn incentive fees. Since high-water marks in new funds are reset, 
investment companies can increase the probability of earning incentive fees and keep earning management fees, by substituting poorly performing hedge funds with new ones.

Hypothesis 2: The probability of launching a new hedge fund increases given the recent liquidation of another hedge fund within the family.

Like mutual fund families (see Khorana and Servaes (1999)), hedge fund families can capitalize on their good reputation by creating new funds. As companies that perform well may expect a higher capital inflow to their new funds, the probability of hedge fund origination should increase with the average past performance of already existing hedge funds within the same company.

Hypothesis 3: The probability of launching a new hedge fund within a family increases with the average returns of existing family-member funds.

By launching and operating funds, investment companies gain experience and accumulate procedural information, including the optimal fund structure and strategy, and the appropriate number of analysts, advisors, secretaries, best brokers and banks. They can capitalize on this information when launching additional funds. In the initial stages, companies acquire a number of licenses (e.g., Registered Investment Adviser, Commodity Pool Operator) and physical assets (computer pools, specially developed software); and new funds can use, at least partially, the assets of existing funds within the family. These scale benefits become more pronounced when the number of already launched funds increases. ${ }^{2}$ Larger families are

\footnotetext{
${ }^{2}$ Khorana and Servaes (1999) use similar arguments for mutual fund origination decisions.
} 
also more visible to investors. Hence, it should be easier for large, experienced companies to launch new funds.

Hypothesis 4: The probability of launching a new hedge fund increases with the number of already existing funds within the family, and with their total assets under management.

\subsection{Signaling vs. timing}

Given that well performing companies are more likely to start new funds, it may be tempting to interpret a fund's opening as a signal of the outstanding quality of the family, which will persist in the future. Performance persistence may indeed depend upon the family structure. Analyzing mutual fund families, Guedj and Papastaikoudi (2008) document the persistent performance of funds belonging to large mutual fund families. They explain this result by the deliberate promotion of well performing funds by their respective families. If the performance of funds within a family persists, then investing in existing hedge funds from families that have just launched a new hedge fund should be a beneficial trading strategy for investors.

This launching signal, however, may prove uninformative with respect to future family performance. Investment companies may engage in a game of optimal timing. They will open a new fund to the public after a period of good luck for already existing funds, in order to enjoy spillover effects. Zhao (2004) documents a similar strategy for fund closure decisions. The author shows that mutual fund families close funds for investment after a period of good performance. The outstanding performance of closed funds does not persist in the future, but investors seem to treat the fund closure for further investment as a signal of good family quality, and they increase inflows to other funds within the family. In the light of this observation, the following hypothesis should be tested: 
Hypothesis 5: Existing hedge funds within fund families outperform prior to the opening of new hedge funds, but not afterwards.

\subsection{Capital inflow to new hedge funds}

The strategic liquidation of underperforming funds and timing the launch of new funds make sense only if spillover effects to new funds indeed exist and inflows to new funds increase with the past performance of other family-member funds. Existing research has proven the significance of spillover effects in mutual fund families (Khorana and Servaes (1999), Nanda, Wang and Zheng (2004), and Chen and Lai (2010)). In the following, I test for the existence of a similar spillover to new funds in hedge fund families:

Hypothesis 6: Capital inflows to newly originated funds within fund families increase with the past performance of other family-member funds.

If investment companies successfully follow the tactics described above, they should be able to attract higher inflows to their newly originated funds than companies that are starting their first fund. Families may capitalize on their established reputation: investors are likely to have more information about existing companies, and can treat investments in their new funds as less uncertain; they may also be able to learn more quickly about new funds started within the established families. All these factors may positively influence the inflow into new funds. 
Hypothesis 7: New hedge funds originated within already existing families enjoy higher inflows than other new funds, and this is driven by the spillover to new funds, reputation, and the strategic behavior of the families.

\subsection{Managerial monetary compensation}

Mutual fund managers have strong incentives to increase the sizes of their funds, as their compensation is proportional to the fund's assets under management (see Chevalier and Ellison (1997)). In the hedge fund industry, a substantial part of managerial compensation comes from incentive fees - a share of profits over the high-water mark. Given the same percentage returns, larger hedge funds earn higher incentive fee compensation. The profitable investment opportunities exploited by hedge funds may be, however, limited. An increase of the assets under management beyond some optimal point may adversely impact a fund's performance (see Goetzmann, Ingersoll and Ross (2003)).

If hedge fund families are experienced in promoting their funds and can ensure higher inflows, then their managers should be able to earn higher income from the management fee at least. If, in addition, the adverse impact of fund size on performance is offset by a size increase, the dollar incentive fees of managers from the multi-fund companies should also be higher than those of managers from the single-fund companies.

Hypothesis 8: The managers of new hedge funds originated within already existing families earn higher monetary compensation from both management and incentive fees than their peers in single-fund families. 


\section{Modeling remarks and variable choice}

\subsection{Liquidation of hedge funds within fund families}

The hedge fund liquidation hypothesis is tested using a logit regression, based on all hedge funds from multi-fund companies. The dependent variable $y_{i, t}^{L}$ takes a value of one if a hedge fund $i$ is dropped from the live database at month $t$. For other funds that existed within the same company on the date of exclusion, but were not removed from the live database, the corresponding dependent variables take a value of zero. The monthly observations ( $0 \mathrm{~s}$ and $1 \mathrm{~s})$ are pooled together for all funds and all months from January 1994 to June 2006.

$$
\begin{aligned}
& y_{i, t}^{L}=\left\{\begin{array}{l}
\left.1, \text { if } y_{i, t}^{L^{*}}>0 \text { (hedge fund } i \text { is liquidated on date } t\right) \\
0, \text { otherwise. }
\end{array}\right. \\
& y_{i, t}^{L^{*}}=\text { Const }+ \text { Absolute _ characteristics } s_{i, t} \cdot \beta \\
& + \text { Relative }_{\text {characteristics }}, \cdot \delta \\
& + \text { Liquidation_controls }_{i, t} \cdot \gamma+\eta_{i, t}
\end{aligned}
$$

$y_{i, t}^{L^{*}}$ is a latent variable that depends on a set of explanatory variables. The error term $\eta_{i, t}$ follows a logistical distribution.

The set of explanatory variables includes the absolute characteristics of hedge funds and their performance (Absolute_characteristics ${ }_{i, t}$ ), the values of these characteristics relative to the company average (Relative_characteristics $s_{i, t}$ ), and a set of controls (Liquidation_controls $s_{i, t}$ ). Under the null of strategic fund liquidation by investment companies (Hypothesis 1), I expect to find significant loadings on the relative factors $(\delta)$. 


\subsubsection{Control variables}

The commonly used controls for liquidation-related hypotheses include fund performance, risk, size, and managerial incentives.

In this paper, I measure hedge fund performance as the average return earned by a hedge fund during the last year prior to its liquidation, or the liquidation of another fund within the same family, and hedge fund risk as a standard deviation of the return series. Hedge fund size is measured as the natural logarithm of the average assets under management of the fund during the last year. I expect hedge fund returns and assets under management to be negatively related to the liquidation probability, whereas I expect the return standard deviation to be positively related to the liquidation probability.

The levels of management and incentive fees, the length of lockup and notice periods, and the fund value relative to the high-water mark proxy for managerial incentives and flexibility. Appendix A provides the computational details of the high-water mark and the relative value. I expect to find negative relationships between the probability of fund liquidation and fees, restriction periods, and the relative fund value.

All the factors discussed above reflect the absolute performance characteristics of hedge funds. To capture the relative position of a fund within its family, I use deviations of hedgefund-specific factors from their average values across other funds within the same company.

In addition to the key variables of interest, two control variables are included in the regression. The first is the number of existing funds within a company, which is expected to be negatively related to the liquidation probability. ${ }^{3}$ The second control variable is the starting date of a fund, which makes it possible to control for the hazard rate variation over time.

\footnotetext{
${ }^{3}$ This holds if a company can liquidate only a limited number of hedge funds within each period.
} 


\subsection{Origination of new hedge funds within fund families}

The origination-related hypotheses are also tested in a logistic regression framework. The dependent variable $y_{i, t}^{O}$ represents a company decision to launch a new fund. It takes a value of one if company $i$ starts a new fund during month $t$ and zero otherwise. These monthly observations (0s and 1s) are pooled together for all companies and all months from January 1994 to June $2006 .^{4}$

$$
\begin{gathered}
y_{i, t}^{O}=\left\{\begin{array}{l}
1, \text { if } y_{i, t}^{O *}>0(\text { company } i \text { starts a new fund on date } t), \\
0, \text { otherwise. }
\end{array}\right. \\
y_{i, t}^{O^{*}}=\text { Const }+\left[{\text { Family_Return } \left., N F u n d s, \text { TotalAuM }, D^{l i q}\right]_{i, t} \cdot \beta} \cdot \beta\right. \\
+ \text { Origination_controls }{ }_{i, t} \cdot \gamma+\eta_{i, t}
\end{gathered}
$$

$y_{i, t}^{O^{*}}$ is a latent variable that depends on hypotheses-related explanatory factors and a set of controls $\left(\right.$ Origination_control $\left.s_{i, t}\right)$. The error term $\eta_{i, t}$ follows a logistical distribution.

The influence of the liquidation decision on the origination decision (Hypothesis 2) is captured by a dummy variable $D^{l i q}$, which takes a value of one if, during a year prior to or following after the hedge fund origination, any hedge fund has been liquidated within the company.

The average return earned on the existing funds within the family during the last half year prior to the origination date (Family_Return) relates to Hypothesis 3. Positive and significant loading on this factor supports the intuition that well-performing families are more likely to start new funds. Hypothesis 4 is related to the number of funds within the company existing

\footnotetext{
${ }^{4}$ As a robustness check, the model is estimated using yearly aggregated date. The dependent variable takes a value of one if company $i$ starts at least one hedge fund during year $t$, and zero otherwise. All the control variables are the averages over the previous year. The results are similar to those based on the monthly data.
} 
on the date of interest (NFunds) and the natural logarithm of the last half-year average total assets under management of the existing funds (TotalAuM).

\subsubsection{Control variables}

The control variables for the origination-related hypotheses include, first, the half-year average cross-fund standard deviation of the returns, to proxy for company diversification, and second, three dummy variables related to fees and restriction periods. The first dummy takes a value of one if the asset-weighted average management fee of the existing hedge funds of the company is below the industry median, the second takes a value of one if the asset-weighted average incentive fee of the existing hedge funds is below the industry median, and the last dummy takes a value of one if the asset-weighted average notice period prior to redemption of the existing hedge funds of the company is below the industry median. These variables should control for company incentives to start new funds in order to change contractual terms (fees and restriction periods) in a favorable way. Those companies that charge lower fees and have shorter restriction periods have the most to gain by launching new funds. Khorana and Servaes (1999) document that mutual fund families having a greater proportion of funds with lower fees open more funds.

General market characteristics, such as the average return on the S\&P 500 index and the average hedge fund industry return computed during the last half year prior to the fund's creation, capture the time variation of the opportunity set of fund families. When the market is booming, more free cash is likely to be available for further investment. Demand for hedge fund services increases, leading to the enlargement of already existing funds and making the opening of new hedge funds more probable. 


\subsection{Signaling vs. timing}

To test for the strategic timing of a hedge fund start, that is, whether existing funds in a family outperform an average hedge fund before the creation of a new fund but fail to do so afterwards (Hypothesis 5), two sets of equally weighted portfolios are constructed: "prelaunch" portfolios and "post-launch" portfolios. Each set consists of two portfolios. The first portfolio in each set, labeled "families-based", includes hedge funds that belong to the launching families, and the second portfolio, labeled "random", consists of randomly chosen funds. In what follows, the construction of the pre-launch portfolios is discussed in detail.

Let us denote an investment period by $\tau$. $\tau$ will take two values: half a year, to investigate short-term portfolio performance, and one year, to investigate longer-term performance. In constructing the families-based portfolio, for each family that has several funds with at least one of them being launched later than the others, funds in existence $\tau$ periods before the new fund launch are added to the portfolio for these $\tau$ periods. If any one of these funds stops reporting within the investment period, I assume that it will earn zero returns until the end of the period. ${ }^{5}$ It would be unrealistic to assume that an investor can immediately reallocate redeemed shares to new funds, since hedge fund share redemption can take up to one year.

To ensure the same level of diversification in the families-based and random portfolios, both portfolios include equal numbers of funds at each point in time. When adding hedge funds to the families-based portfolio for the calendar period from $t$ - $\tau$ to $t$, I randomly pick the same number of funds from the population of all hedge funds existing at time $t-\tau$, and include them in the random portfolio for the next $\tau$ periods. As in the families-based portfolio, if any random fund stops reporting during the investment period, its returns are set to zero until the end of that investment period. After the portfolio choice is completed, that is, all fund

\footnotetext{
${ }^{5}$ This assumption is consistent with Ackermann, McEnally and Ravenscraft (1999) and Hodder, Jackwerth and Kolokolova (2010), who document rather small, albeit negative, hedge fund delisting returns.
} 
families are considered, the portfolio returns are computed as a simple average of individual fund returns.

The post-launch portfolios are constructed analogously, with only one difference: the postlaunch families-based portfolio includes the hedge funds that existed within a family before the launch of a new fund, but it is invested in these funds for $\tau$ periods after the start of a new fund. The newly originated funds are not included in the portfolio. The random portfolio is based on the complete fund population, excluding newly originated funds.

In the next step, the pure and risk-adjusted performance of the pre- and post-launch versions of the families-based and random portfolios is compared. I test for the significance of the mean return difference, and of the difference in the Sharpe ratios of the portfolios. For the Sharpe ratios, I use the test statistic developed by Jobson and Korkie (1981) with the Memmel (2003) correction (which controls for different variances of the portfolio returns and their correlation). To account for possible differences in the factor exposures of these portfolios and nonlinearities in the hedge fund investment strategies, I consider a hypothetical joint portfolio that longs the families-based portfolio and shorts the corresponding random portfolio. The returns on the resulting long/short portfolio are regressed on seven factors ${ }^{6}$, as developed by Fung and Hsieh (2004). The key variable of interest in this regression is the constant term, which is an estimate of the alpha difference between the families-based and random portfolios.

If the start of a fund is not an informative signal of outstanding family quality, but the superior performance of family-member funds prior to new fund origination simply reflects the timing of the fund start, the families-based portfolio should exhibit a higher mean and

\footnotetext{
6 The time series of the factors can be obtained from the web page of David Hsieh, http://faculty.fuqua.duke.edu/ dah7/HFRFData.htm.
} 
higher Sharpe ratio, and the long-short portfolio should have a positive and significant alpha during the pre-launch period, but not during the post-launch one.

\subsection{Capital inflow to new hedge funds}

\subsubsection{Capital inflow to new hedge funds within fund families}

To test the relationship between flows to new funds and the past performance of existing family-member funds (Hypothesis 6), I regress the flow to the newly originated funds $\left(\right.$ NewFundFlow $\left._{i}\right)$ on a constant term, the average return earned on other family-member funds $\left(\right.$ Family_Return $\left._{i}\right)$, a set of family related controls (Family_Controls $)_{i}$, and a set of general control variables $\left(\right.$ Controls $\left._{i}\right)$, which, in the literature, are found to be significant predictors of fund flow. This regression is based solely on funds launched within families that have at least one fund in operation on the date of the new fund opening. The error term $\varepsilon_{i}$ is normally distributed, and may be heteroscedastic.

$$
\text { NewFundFlow }_{i}=\text { Const }+\mu \cdot \text { Family_Return }_{i}+\phi \cdot \text { Family_Controls }_{i}+\beta \cdot \text { Controls }_{i}+\varepsilon_{i}
$$

In most fund-flow research, flows are measured as a percentage of the previous month's assets under management. The same percentage flow, however, can correspond to very different absolute flows for funds of different sizes. To establish whether one particular new fund is more attractive to investors than another, it is not sufficient to consider only

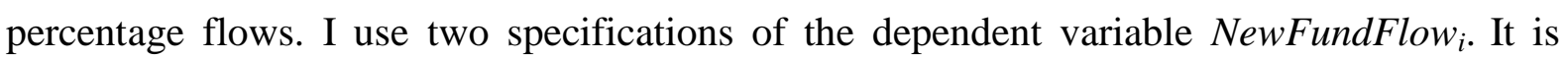
measured, first, as an average absolute monthly flow into a new fund for $\tau$ months after its origination; and second, as an average monthly percentage flow during this period. To assess 
the stability of this effect, half-yearly and yearly horizons are considered. To diminish the effect of outliers, the highest $1 \%$ and the lowest $0.5 \%$ of fund flow estimates are trimmed ${ }^{7}$.

Monthly absolute flow is measured as the difference between the end-of-month assets under management and the assets under management as of the end of the previous month, adjusted for this month's return.

$$
\text { AbsFlow }_{t}=A u M_{t}-A u M_{t-1}\left(1+r_{t}\right),
$$

Monthly percentage (relative) flow is measured as the ratio of the absolute flow to the assets under management as of the end of the previous month:

$$
\operatorname{RelFlow~}_{t}=\frac{A u M_{t}-A u M_{t-1}\left(1+r_{t}\right)}{A u M_{t-1}},
$$

where AbsFlow ${ }_{t}$ and RelFlow $t$ are the absolute and percentage flows, respectively, during period $t, A u M_{t}$ is the assets under management as of the end of period $t$, and $r_{t}$ is the post-fee return earned by the fund during period $t$.

Family_Return $_{i}$ is the average return of the existing funds within the family over the $\tau$ months prior to the new hedge fund start. I use the same value of $\tau$ ( 6 or 12 months) as that one used for the construction of NewFundFlow .

\subsubsection{Control variables}

This section discusses several family-related control variables that may influence the fund flow pattern.

If a new fund is expected to perform as well as already existing funds, then investors would prefer families with a better risk/return tradeoff. The higher the share of company

\footnotetext{
${ }^{7}$ Ding, Getmansky, Liang and Wermers (2009) also trimmed their sample, in order to prevent outliers from affecting the results.
} 
assets invested in the same style as that of newly launched hedge fund, the more experienced the family may seem to be in executing this style. This may result in an increasing inflow into the new hedge fund. Old families may have a reputation for providing stable performance over a long period, and the flow to the new funds could increase with family age. Family heterogeneity may also play a role. If a family is very heterogeneous (i.e., there exist funds that perform well and poorly simultaneously), this may indicate that the next originated fund may be rather different from the already existing ones. Investors may be less attracted to these funds, since higher uncertainty is associated with their quality. Additionally, investment companies may try to redirect capital from funds liquidated earlier to their new funds. In that case the flow to the newly originated fund could increase, conditional on the prior liquidation of another fund within the same family.

Following this intuition, I include as family-related control variables the average return standard deviation of member funds computed during the same period as the average prelaunch return, cross-fund return standard deviation, the assets under management of funds within the family that follow the same style as the newly originated fund, the assets under management of funds following different styles, company age, and a liquidation dummy. The dummy takes a value of one if, within a year prior to the new fund's opening, any other fund was liquidated within the company.

In assessing the existence of the spillover effect, one should control for other (family irrelevant) factors that potentially influence the fund flow, such as the past performance of a fund, the performance of other funds following the same style, fund fees, and fund size. The relationship between different hedge fund characteristics and flow is very complex, and differs considerably from that of mutual funds. A detailed discussion of the general controls used in this paper is provided in Appendix B. 


\subsubsection{Capital inflow to all new hedge funds}

To test whether hedge fund families succeed in generating higher inflows to their new funds, relative to funds launched not within families (Hypothesis 7), a regression similar to (5) is estimated, based on both the absolute and relative flows to all new funds ${ }^{8}$. In this case, family-related controls are substituted by a family dummy $\left(D_{\text {Family }}\right)$. It takes a value of one if a fund of interest is not the first fund launched within its family, and zero otherwise. The error term is normally distributed, and may be heteroscedastic.

$$
\text { NewFundFlow }_{i}=\text { Const }+\lambda \cdot D_{\text {Family }, i}+\lambda^{+} D_{\text {Family }, i}^{+}+\lambda^{-} D_{\text {Family }, i}^{-}+\beta \cdot \text { Controlls }_{i}+\varepsilon_{i}
$$

A positive and significant loading on the family dummy $D_{\text {Family }}$ indicates that investors are more likely to allocate larger amounts of money to hedge funds launched within already existing families.

The dummy variable ${D^{+}}_{\text {Family }}$ controls for the impact of the spillover effect on the flow within families. It takes a value of one if a new fund is launched within a family with an average return over the six months prior to fund start above the industry median. The loading on this dummy is expected to be positive and significant.

The dummy variable $D_{\text {Family }}^{-}$proxies for the likely strategic timing of the fund start. It reflects the existence of a short period of good luck for hedge funds belonging to a family that does not perform persistently well. The variable takes a value of one if the fund is launched within a family, the family performance over the last half year prior to fund start

\footnotetext{
${ }^{8}$ Note, here hedge fund performance during the first several months after origination is considered and we are likely to encounter backfilled returns. These returns may be higher than average, and fund flow may be biased upwards. However, since I investigate the difference between flows to families-based and stand-alone funds, the backfilling bias is likely to be canceled out, and $\lambda$ is a consistent estimate of the average flow difference.
} 
lies in the top tercile compared to industry returns, but the average family performance six months before (that is, from the $12^{\text {th }}$ to $6^{\text {th }}$ month prior to the fund start) is below the median performance of the industry. Those funds for which $\mathrm{D}^{-}$Family equals one are likely to be engaged in the strategic timing of the fund start. If the strategic timing of fund start is a success, the loading on $D^{-}$Family will not be significant. A negative and significant loading on this dummy would indicate that investors are aware of the strategic decisions of investment companies.

\subsection{Managerial monetary compensation}

The compensation of hedge fund managers consists of two main parts: a management fee and an incentive fee. The management fee is normally paid at the end of each month, as a percentage of the assets under management, which is $1 / 12$ of the yearly rate reported in the database. The incentive fee is paid yearly, based on hedge fund profits over a high-water mark, as of year end. It is, however, subtracted from the reported net asset value of the hedge fund each month. The reported returns are thus net of all fees, including the actually paid management fee and the accrued incentive fee.

The reported (post-fee) assets under management at month $t, A u M_{t}$, exclude the management fee paid for this month's Dollar_MgmtFee ${ }_{t}$, which is based on the pre-fee assets under management. If $\mathrm{MgmtFee \%}$ is a yearly percentage management fee charged by a fund, the monetary management fee earned by a manager during month $t$ can be computed as

$$
\text { Dollar_MgmtFee }_{t}=\frac{\text { MgmtFee\% } \cdot \text { AuM }}{12\left(1-\frac{\text { MgmtFee\% }}{12}\right)},
$$

The accrued incentive fee is based on the pre-fee hedge fund returns. Following an approach developed in Hodder, Jackwerth and Kolokolova (2010), and an earlier paper by 
Brooks, Clare, and Motson (2008), I reconstruct the pre-fee returns by adding both management and incentive fees back into the reported returns. The detailed procedure is outlined in Appendix C. The percentage incentive fee accrued in month $t, \operatorname{IF}(t)$, then equals

$$
I F(t)=\max (0, N A V(t)-H W M) \cdot\left(\frac{1}{1-\text { IncentiveFee\% }}-1\right)
$$

where $N A V(t)$ is the reported net asset value of the fund at the end of month $t$, which equals the product of the reported hedge fund returns from fund origination until month $t ; H W M$ is the high-water mark applied for month $t$, computed as in Appendix A, and IncentiveFee\% is the percentage yearly incentive fee, as reported in the database.

The exact dollar amount of the accrued incentive fee, Dollar_IncentiveFee ${ }_{t}$, is computed after the management fee has been paid. It is therefore based on the reported assets under management:

$$
\text { Dollar_IncentiveFee }_{t}=I F(t) \cdot A u M_{t},
$$

To test Hypothesis 8, I compare the average dollar management fee and the average dollar accrued incentive fee earned by hedge funds over the first year after origination, and the last year prior to liquidation within single-fund and multi-fund families. Additionally, fee income is estimated for middle-aged funds during the third year of their life. The average lifetime of hedge funds in the ALTVEST database used for this study is 4.67 years. Thus, an average fund is already relatively mature in its third year, but any indications of possible future failure should not yet be pronounced. Those funds that become defunct before or during the third year after origination are dropped from the group of middle-aged funds. 
As the monetary managerial compensation is determined by hedge fund size, returns, and nominal percentage fees, these characteristics are compared across hedge funds from both single-fund and multi-fund families.

\section{Data}

The main source of information for the current study is the ALTVEST database ${ }^{9}$. It contains monthly returns, assets under management, managerial and incentive fees, notice periods prior to redemption, lockup periods, and investment company identification for more than 6800 hedge funds. ${ }^{10}$ For the purposes of the paper, only those funds that report their returns in US dollars between January 1994 and June 2006 are included in the sample. The database records the performance of defunct funds, and the survivorship bias is less pronounced in the data. The database reports managerial names for most live funds, but no such information is available for defunct funds. Thirty-six defunct hedge funds in the ALTVEST database were removed from the live database because of duplicate registration. To avoid double counting the same funds, these funds are deleted from the sample. Since funds of funds can differ substantially from single- and multi-strategy funds (see Agarwal and Kale (2007)), I exclude funds of funds from the analysis. While cleaning the data, two hedge funds were found that reported several returns over $400 \%$ per month. These funds are excluded from the sample, since they are likely to have reported the performance inaccurately.

\footnotetext{
${ }^{9}$ The ALTVEST database is provided by Morningstar.

${ }^{10}$ The ALTVEST database is also used by Griffin and Xu (2009) within the combined databases constructed by the authors; selected funds from the database are used by Lo (2001) and Lo (2002); the hedge fund indices provided by the ALTVEST database are discussed in Amenc, Martellini, and Vaissie (2003).
} 
The ALTVEST database contains information on more than 2000 different companies that operate hedge funds, and report returns in US dollars. On average, each company controls 2.23 funds. Forty-seven per cent of the companies operate more than one fund, and they control in aggregate more than $70 \%$ of all the hedge funds in the database (Table 1).

The final sample includes 4873 individual hedge funds, 3711 of which are controlled by multi-fund companies. There are 1620 live funds, and 2091 defunct funds. The sample statistics of the data are reported in Table 2, and are broadly consistent with common sense intuition. Live funds controlled by both multi-fund and single-fund companies have lower return standard deviations and higher Sharpe ratios than the corresponding dead funds. Hedge funds belonging to multi-fund families have lower mean returns ${ }^{11}$ and lower return standard deviation than funds from single-fund families, which results in comparable Sharpe ratios.

Four main hedge fund styles are represented in the ALTVEST database. The largest is Equity Long/Short, which accounts for around $43 \%$ of hedge funds. Directional funds excluding Equity Long/Short represent about $20 \%$ of the database. Relative Value and Event Driven funds account for $23 \%$ and $14 \%$, respectively. Details concerning the investment style classification in the ALTVEST database are presented in Appendix D.

Table 3 reports the distribution of companies with respect to the styles used by their underlying funds. Each fund is classified into a particular style if it reports investing more than $50 \%$ of its assets in this style. Funds that have no dominating style are classified as multi-strategy funds. The investment companies represented in the ALTVEST database seem to be rather specialized. Around $50 \%$ of the multi-fund companies specialize in Equity Long/Short funds. Directional and Relative Value funds each dominate in about $17 \%$ of companies. Thirteen percent of companies seem to have an expertise in Event Driven funds, and the rest specialize in multi-strategy funds. Among those companies that control more

\footnotetext{
${ }^{11}$ Boyson (2008) also documents that hedge funds from larger families tend to have lower mean returns.
} 
than one fund, on average $89.4 \%$ of funds belonging to each company follow a common style. The level of company diversification increases with the number of funds. Among those companies that control 10 or more funds (53 companies), on average $70.87 \%$ of funds in each company follow one common style. A company operating ten funds will thus have seven funds in the style in which the company has expertise, and the remaining three funds will follow other styles.

Table 4 reports the descriptive statistics of the monthly absolute and percentage flows computed for all funds (Panels A1 and B1) and for new funds during their first six months after origination (Panels B1 and B2).

On average, the absolute monthly flow to funds belonging to multi-fund families is higher than that to those belonging to single fund families (US\$ 1.055 million vs. US\$ 0.619 million). However, funds from multi-fund families seem to be larger, and the relative flow to funds belonging to multi-fund families is significantly lower than that to funds belonging to single-fund families $(2.0 \%$ per month vs. $2.6 \%$ ). This effect seems to be driven by dead funds. The mean percentage flows to live funds from single-fund families and multi-fund families are not significantly different from each other. At the same time, during the first six months after origination, hedge funds belonging to multi-fund families enjoy a higher inflow than those belonging to single-fund families, in both absolute and percentage terms.

For the purpose of the paper, it is essential to establish the actual starting date of hedge funds. Most databases are subject to backfilling bias, because hedge funds can "back fill" their past returns upon entering the database. Normally, this is done only if the past performance helps to improve the track records of hedge funds. However, the ALTVEST database requires hedge funds to report the complete return history from fund origination when listing in the database. Comparing the inception dates of hedge funds and the dates of their first reported return, I find that a median hedge fund indeed reports the complete return 
history; and that $90 \%$ of hedge funds start reporting their performance no later than 2 months after inception. Thus, the first date of the available return history is a relatively precise indicator of the actual launch date of a hedge fund.

\section{Empirical results}

\subsection{Liquidation of hedge funds within fund families}

Table 5 reports the estimation results for the logit model of hedge fund liquidation. The liquidation probability is first related to the absolute hedge fund characteristics and, second, the characteristics relative to the family average are added. When no family-related factors are included (column 1 of Table 5), the average fund return six months prior to liquidation, the logarithm of its assets under management, and the percentage flow are negatively related to the liquidation probability, which is in accordance with the existing literature. After the inclusion of the factor values relative to the company average (column 2 of Table 5), the absolute factors lose significance. Only the loading on the percentage flow remains negative and highly significant. The relative factors on the contrary gain significance. Investigating whether the liquidation probability depends on fund style, I also include the style dummies, none of which turns out to be significant.

Consistent with Hypothesis 1, hedge funds having higher than company average mean return and assets under management, higher flows, larger management fees, a longer notice period prior to redemption, and a higher value relative to the high-water mark are less likely to be liquidated. The augmented model also has higher explanatory power. The McFadden Rsquared increases from 0.125 to 0.191 , and the Estrella R-squared increases from 0.136 to 0.210 . 


\subsection{Origination of new hedge funds within fund families}

Table 6 reports the estimation results for the logit regression of hedge fund origination. The intuition of Hypothesis 2 is supported by the data: the probability of starting a new fund increases for those families that decide to liquidate any other fund within a year before or after the new fund origination. The corresponding loading of 0.148 is significant at the $5 \%$ level.

The results crystallize even more strongly if the single liquidation dummy is split into two variables: the first takes a value of one if the liquidated fund had a higher mean return than the hedge-fund industry average over the quarter prior to liquidation, and the second takes a value of one if the liquidated fund had a lower mean return than the industry average. The loading on the second dummy is 0.185 and significant, whereas the loading on the first dummy is not significant. Other factor loadings are almost identical to those in Table 6, and are not reported here. This indicates that hedge fund families tend to replace those familymember funds that perform poorly with new hedge funds.

Consistent with Hypotheses 3 and 4, the probability of a new fund launch increases with the average return of other member funds prior to fund start, with the number of funds that have been launched earlier by that family, and with the total assets under management in the

family. The corresponding loadings are highly significant. Hence, family experience and success increase the likelihood of a new fund start in hedge fund families, similar to mutual fund families.

Surprisingly, if a hedge fund family has on average lower fees than the industry median, it is less likely to start new funds. This finding contradicts the results obtained for mutual funds, as mutual fund families with lower fees tend to open new funds in order to reset fees to a higher level. 
There is some evidence that hedge funds are more likely to be launched when the overall market performs well. The loading on the S\&P 500 index return is positive and significant at the $10 \%$ level. The average performance of the hedge fund industry does not seem to have any impact on the probability of a fund start. This may be due to heterogeneity between hedge funds following different styles. The average hedge fund industry return may not fully reflect the attractiveness of different hedge fund styles.

The style composition of fund families (Table 3) suggests that hedge fund families are rather specialized. This leads to a natural extension of the fund origination hypothesis. Company experience may be style-specific, and the probability of a new fund launch with a particular style may increase with the number of already existing funds with the same style in that company.

To check for this effect, I estimate logit models of fund origination for subsamples of funds that are launched with one of the four styles. The total number of funds existing within the company on the origination date is now split into the number of already existing funds with the same declared style as that of the new fund and the number of funds declaring any other style. Company experience indeed seems to be style-specific. The number of existing funds within a family with the same style as the newly originated one has a positive and highly significant impact on origination probability for all styles. The loadings on the number of funds vary from 0.228 for Equity Long/Short funds to 0.553 for Directional funds. The number of funds following different styles has a negative and significant impact on origination probability for all styles, with the exception of Directional, where the coefficient is not significant. ${ }^{12}$ Similar evidence exists for another type of financial institution-insurance

\footnotetext{
${ }^{12}$ I also control for the assets under management invested within the same style in the company, but this variable turns out to be insignificant.
} 
companies - for which specialization in one particular area is more beneficial than diversification across different lines of business (see Cummins, Weissa, Xieb, and Zi (2010)).

\subsection{Signaling vs. timing}

To consider whether hedge fund families strategically time a new hedge fund start, Table 7 reports the descriptive statistics of pre- and post-launch families-based portfolios and the corresponding random hedge fund portfolios.

Six months before fund origination, family-member funds outperform their peers. The families-based portfolio provides an average return of $1.25 \%$ per month, which is significantly higher than that of the random portfolio (1.09\%). Moreover, it also delivers a higher Sharpe ratio, with the difference being significant at the $1 \%$ level. This effect becomes less pronounced if one considers a period of one year prior to fund launch. Average portfolio returns are no longer significantly different, and the difference in Sharpe ratios is significant only at the $10 \%$ level.

After the launch of a hedge fund, families-based portfolios do not outperform the random portfolios on either horizon. The mean returns of the families-based and random portfolios do not differ significantly from each other. In addition, the random portfolios seem to have higher Sharpe ratios, with the differences significant at the 5\% level.

A similar pattern is observed if one considers the alpha of a hypothetical portfolio that longs the families-based portfolio of hedge funds and shorts the random portfolio (Table 8). The alpha of this portfolio combination (based on the six months investment horizon prior to fund origination) is approximately 19.9 b.p. per month, and is significant at the $1 \%$ level. It decreases by a factor of two to 9.5 b.p. per month if the portfolio based on the 12-months investment horizon is considered, and becomes only marginally significant. The alphas of the post-launch portfolio combinations are not significantly different from zero for both horizons. 
The low values of R-squared, and virtually no significant factor loadings in the post-launch regressions, indicate that the hedge funds from the multi-fund companies in the post-launch period are not different from the other funds in the industry, with respect to both their abnormal return (alpha) and risk-exposure.

The results discussed above are based on all hedge funds. I repeat the analysis separately for hedge funds following four main styles: Equity Long/Short, Directional, Relative Value, and Event Driven. The results based on the largest style of the database - the Equity Long/Short funds - are very similar to those presented above. The results for other styles are weaker, since the number of families specializing in funds other than Equity Long/Short is relatively small. The alphas of the hypothetical long-short portfolios are no longer significant, either for the pre-launch or the post-launch cases, and the pre-launch mean returns of the families-based portfolios are not significantly different from the corresponding random portfolios. Nevertheless, the pre-launch families-based portfolios have higher Sharpe ratios than the corresponding random portfolios. The difference is especially pronounced for the Event Driven funds.

Summing up these results, we can conclude that, within hedge fund families, member funds outperform prior to new fund origination. This superior performance seems to be a rather short-lived trend, which is pronounced six months before origination, but is hardly noticeable on a yearly horizon. Launch time itself is likely to be strategically chosen immediately after a positive trend in family performance becomes sufficiently pronounced. The empirical results indicate that families do not continue to exhibit superior performance, on either a pure or a risk-adjusted basis, after a new fund launch. Thus a launching decision does not indicate outstanding family quality, and should not be interpreted as a positive signal. Nevertheless, by optimizing the launch time, investment companies may try to 
"persuade" the market that they are of good quality, and increase the flows to their new funds.

\subsection{Capital inflow to new funds}

Table 9 reports the estimation results of regression (5), which tests the existence of the spillover effect in hedge fund families. ${ }^{13}$ Consistent with Hypothesis 6, the mean return earned by other family-member funds has a statistically significant and positive effect on both absolute and percentage flows to newly originated funds. It is pronounced at all the horizons investigated, and it is economically significant. A one percent increase in average family return leads to an increase in the average monthly absolute flow to newly originated funds during the first year of US\$ 0.216 million.

Several other family-specific controls are worth mentioning here. First, the average standard deviation of the returns of the member funds (measuring how volatile on average the returns of each individual family-member fund are) has a negative and, in most cases, significant impact on flows to new funds. The more uncertainly is associated with other family members, the more reluctant investors are to invest in the new funds of this family. Second, investors seem to believe in family experience and specialization. Absolute flows to a new fund within a family increase with the assets under management invested within the family in the same style as that of the new fund. And last but not least, the decision to liquidate a hedge fund within one year prior to a new fund launch leads to lower percentage flows to new funds, indicating that families fail to redirect capital from the liquidated funds to

\footnotetext{
${ }^{13}$ In the reported regression, only those controls are included that have a significant impact on fund flow in at least one regression, or are economically relevant. Using all other controls, including hedge fund styles, does not change the main conclusions. The style-variables turn out to be insignificant.
} 
the new ones under their control, and that investors treat fund liquidation as a negative signal regarding family quality.

One should also note the very low explanatory power of the regression for percentage flow. This indicates that, even though several significant relations between flows to newly originated funds and explanatory variables of interest can be documented, the complete variation of the flows cannot be captured. Flows to new funds may be influenced by personal managerial investment and the investment activities of the principal shareholders.

Overall, families seem to succeed in generating higher flows to their new funds. Table 10 reports the estimation results of regression (8). Supporting the intuition of Hypothesis 7, hedge funds launched within already existing families have higher absolute and percentage flows than hedge funds originated by a completely new family. During the first six months after origination, family-member funds have on average $2.6 \%$ per month higher percentage flows, and \$0.340 million per month higher absolute flows than their peers not launched within families. These effects seem to be economically relevant, given that the average monthly flows to all funds during their life are $2.1 \%$ or $\$ 0.953$ million (see Table 4 , Panels A1 and B1). This effect is independent of family performance and reflects purely the advantage of being launched within an already established company known to investors.

In addition to this effect, the spillover to new funds is very pronounced. Both absolute and relative flows to new funds within families increase greatly if the average performance of other member funds half a year prior to a new fund start is above the industry average. This result is consistent with that reported in Table 9 for multi-fund families only.

Remarkably, the fund flow does not seem to be sensitive to the possible strategic timing of a hedge fund start. The dummy variable $D_{\text {Family }}^{-}$is not significant in any of the specifications. The strategic choice of the fund launch time after a short period of superior performance by other family-member funds seems to be beneficial for investment companies, even if they do 
not perform persistently well. Sophisticated hedge fund investors do not seem to punish such funds by lower inflow. A similar effect is documented by Chen, Cheng, Cheng and Chih (2010) for private equity placement. The authors find that, although firms issuing private equity overstate their earnings prior to the equity placement announcements, sophisticated investors do not ask for a fair discount when purchasing these shares.

\subsection{Managerial monetary compensation}

Table 11 reports the average management and incentive fee income earned by hedge fund managers during the first year after origination, the third year after origination, and during the last year prior to liquidation. After origination, hedge funds launched within multi-fund companies receive on average much higher monetary compensation (from both management and incentive fees) than funds launched as single-funds in their companies. Hedge funds from multi-fund families receive on average US\$ 0.050 million per month from their management fee, and have on average a US\$ 0.820 million accrued incentive fee. These figures are significantly higher than the fee incomes of their peers from single-fund families, which are US\$ 0.026 million and US\$ 0.534 million, respectively.

For middle-aged funds and funds close to liquidation, the average management fee earned within multi-fund families is also significantly higher than that earned by hedge funds from single-fund families (0.094 vs. 0.049 , and 0.098 vs. 0.051 million, respectively), whereas the average accrued incentive fees are not significantly different.

Such differences in monetary compensation do not seem to be driven by differences in the nominal percentage fees charged. Hedge funds from both single- and multi-fund families, have comparable fee structures. The median management fee is $1.5 \%$ for live hedge funds and $1 \%$ for dead funds in both groups. The median incentive fee is $20 \%$ for all subgroups of hedge funds. 
Higher income from the management fees of the multi-fund companies is driven by fund size, as the management fee is proportional to the assets under management. The incentive fee, however, depends not only on fund size, but also on the returns earned by hedge funds. Table 12 reports average assets under management, average returns, and average excess returns over the industry average earned by hedge funds one year after their start, in the third year of their life, and one year prior to liquidation.

Hedge funds from multi-fund companies are on average twice as large as hedge funds from single-fund companies, which is consistent with them having a higher inflow. During the first year after origination, their average assets under management exceed US\$ 40 million, whereas the average assets under management of hedge funds from single-fund companies are below US\$20 million. This relationship translates directly into the fee income in Table 11, in which the monetary management fee is twice as high for funds from multifund companies as it is for those from single-fund companies.

Rather remarkable are the average return patterns in Table 12. Hedge funds controlled by multi-fund companies always have smaller returns than funds controlled by single-fund companies. During the first year, the average returns are $1.37 \%$ and $1.83 \%$ per month, respectively, and the difference is highly significant. This difference, however, is driven by dead funds. The average returns earned by live funds $(1.40 \%$ for multi-fund families and $1.53 \%$ for single fund families) are not statistically significantly different from each other. The difference between the average returns of dead funds $(1.35 \%$ and about $2.00 \%$ per month, respectively) is highly significant.

Note that the average post-launch returns are computed during the first year after origination. The "dead" funds still function during this period: they are liquidated later on. However at the beginning of their life, the "future dead" funds from single-fund families earn higher returns than the funds that will survive during the period investigated, and are of 
smaller size. The average return difference is significant at the $10 \%$ level. These funds seem to be aggressive startups, which gamble from the very beginning. The first year returns of "future dead" and surviving funds from the multi-fund families, on the contrary, do not significantly differ from each other.

The return difference between funds from multi- and single-fund families is slightly mitigated during the third year of the funds' existence. However it remains statistically significant, and it becomes even more pronounced during the last year prior to hedge fund liquidation. Before being liquidated, hedge funds from the multi-fund companies have an average return of only $0.23 \%$ per month, compared to the $1.00 \%$ per month earned by hedge funds from the single-fund companies.

A similar pattern is documented for excess returns over the hedge-fund-industry average. After origination, hedge funds launched within single-fund companies outperform, relative to the industry, by more than the funds launched within the multi-fund companies. During the third year of life, funds from single-fund companies still slightly outperform the industry average, whereas funds from multi-fund families underperform by 7 b.p. per month. This poor performance is driven, however, by dead funds. Prior to liquidation, hedge funds from the multi-fund families underperform substantially relative to the industry, compared to their peers from the single-fund families. The average monthly excess returns over the year prior to fund liquidation are -5.3 b.p. and -77.2 b.p. per month for single-fund families and multifund families, respectively. Over the 6 months prior to fund liquidation, however, average excess returns drop to -57.6 b.p. and -95.5 b.p. per month, respectively. Prior to liquidation, hedge funds from multi-fund families underperform for a longer period (which is consistent with their already poor performance during the third year), whereas the performance of hedge funds from single-fund families deteriorates mainly in the last half year. 
I repeat the analysis separately for hedge funds following different styles. The fee income of funds following a particular style and launched within families is compared to that of funds with the same style launched not within families. The average industry returns are also based only on the funds following the style of interest. The style-based results are broadly in line with the findings discussed above. For Equity Long/Short funds, in addition, the difference between the incentive fee income earned by middle-aged funds from single- and multi-fund families becomes marginally significant, with funds from multi-fund families earning on average 1.13 million US\$ more per month. The only exception is the Event Driven style, for which neither monetary management nor incentive fees differ significantly between families-based and stand-alone funds. Nevertheless the documented return (and excess return) patterns are pronounced, even for the Event Driven funds. During the first year, the monthly excess returns of the stand-alone Event Driven funds are 64 b.p. higher than those of the families-based new Event Driven funds. During the last year prior to liquidation, the excess-return difference increases to 84 b.p. per month.

Multi-fund families seem to be more experienced in attracting new capital into their funds than in delivering superior performance. Nonetheless, the lower returns are more than offset by the large assets under management (especially for newly originated funds), and managers from the multi-fund families still earn a higher income from both management and incentive fees. Multi-fund families tend to keep their poorly performing funds alive longer, until their performance shrinks dramatically. These funds, despite being twice as large as funds from single-fund families, are not able to earn higher dollar incentive fees.

\section{Extensions and robustness}

Brown, Goetzmann and Park (2001) show that hedge fund survival depends on the hedge fund's performance relative to other funds within the industry. To control for the relative 
position of a fund within the industry while investigating the probability of its liquidation, the differences between hedge fund-specific characteristics and the average values of these characteristics across all other funds existing on the date of interest are included as additional control variables. This does not change the results of the analysis reported in Table 5. Hedge fund characteristics relative to the industry average are not significant in the presence of the factor values relative to the company average. Investment companies seem to compare a fund mainly with its peers within the same company, rather than within the whole industry. Additionally, to assess the stability of the results, a model is estimated in which the average returns and their standard deviations are computed based on a yearly (not half-yearly) horizon, prior to hedge fund liquidation. The results are rather similar to those of the main regression. The only difference is that the hedge fund return standard deviation relative to the company average increases in significance. Hedge funds that have a larger return standard deviation within a family are more likely to be liquidated.

The next question is whether the higher flows into family-based new hedge funds during the first year are driven by independent investors' flows, or are completely determined by initial managerial and company investment. Individual investors that are not the founders of the hedge funds are not likely to invest in an absolutely new hedge fund. Meanwhile, there exist funds of hedge funds that focus primarily on emerging hedge funds. Such funds of funds invest in hedge funds that are at least three months old. ${ }^{14}$ Thus, hedge fund flows during the first quarter are likely to reflect mostly internal financing. To control for this fact, the flow regressions (5) and (8) are re-estimated, excluding the first three months of each hedge fund from the analysis. Even after excluding the first three months, the flows to newly originated funds within families are positively related to past family returns, again supporting the existence of a spillover effect. The corresponding coefficients are highly significant.

\footnotetext{
${ }^{14}$ This information is obtained from private discussions with managers of funds of funds.
} 
Comparing the flows to funds launched within families and to stand-alone funds, the family dummy stays significant after excluding the first quarter flows. The values of the corresponding coefficients are comparable with those in Table 10 for the absolute flow regressions, and they decrease somewhat for the percentage flow regressions.

With respect to managerial compensation, several other measures of hedge fund managers' fee income have been compared. Instead of the average monthly management fee earned during a year, I use the total income earned during this period. The total income from the management fee is the sum of the corresponding monthly revenues. The results are similar to those reported in Table 11. Hedge funds belonging to multi-fund companies always have significantly higher income from the management fees than their peers from single-fund families.

The incentive fee is, normally, paid at the year end. The monthly accrued-incentive fee will be paid to managers only for those fund-shares that are redeemed during this month. Just as one could reconstruct only the net fund flow from the available data, the actual composition of monthly outflows and inflows is not known, and the exact earnings of a hedge fund manager cannot be reconstructed. The average accrued incentive fee, which is used in the paper, is one possible proxy. As a robustness check, I use (1) the accrued incentive fee exactly 12 months after origination, at the end of the third year after origination, and 12 months before the fund liquidation, and (2) the sum of the incentive fee paid at the end of the first December after fund origination, and the accrued incentive fee as of month 12 after origination $^{15}$, the sum of the incentive fee paid at the end of the third December after origination, and the accrued incentive fee as of month 36 after origination, and the sum of the last December fee prior to fund liquidation and the accrued fee on the liquidation date. The results are coherent with those in Table 11. New hedge funds launched within multi-fund

\footnotetext{
${ }^{15}$ If the $12^{\text {th }}$ month after origination coincides with December, the December fee only is considered.
} 
families have significantly higher revenues from the incentive fees than the funds launched as single-funds in a family. The p-value increases from 0.026 for the average accrued incentive fee to 0.059 for the last period accrued incentive fee, and to 0.055 for the sum of the December fee and the accrued last period fee. The difference in the incentive fee income earned prior to hedge fund liquidation is not significant.

\section{Concluding remarks}

According to the ALTVEST database, more than $70 \%$ of individual hedge funds belong to fund families - i.e., groups of at least two funds controlled by the same investment company. Such funds are no longer independent of each other; and strategic decisions (such as fund creation and fund liquidation decisions) are likely to be interrelated for these funds. This family-related link between individual hedge funds seems to be under-investigated in the existing literature.

This paper documents that hedge funds families behave strategically when launching and liquidating their funds. One reason for such behavior is the existence of a pronounced spillover effect. Capital inflows to newly originated funds within families increase in the past performance of other family-member funds.

To improve the average track record of the family, investment companies replace poorly performing funds (which also are less able to generate high fee income) with new ones. Hedge funds having smaller returns, lower assets under management, lower fees, and lower value relative to the high-water mark than the family average are more likely to be liquidated.

In order to amplify the spillover effect to new funds, the exact fund launch time is chosen by families after a short period of superior performance by other member funds. Thus, the launching decision itself should not be interpreted as a signal of the positive and persistent skill of the managers operating these funds. New funds seem to be launched after a period of 
good luck for other member funds, which do not continue to outperform after the fund start. Investors, however, do not seem to be aware of this timing game employed by hedge fund families, and they respond to the short-term outperformance of hedge funds by increasing money inflows to new funds launched within the same family, even if the family does not perform consistently well.

Multi-fund families are able to attract higher flows to their new funds from outside investors capitalizing on their reputation and established names, and they also benefit from their strategic choice of the precise time of a new fund start. In particular, they seem to be more experienced in promoting their funds and attracting inflows than in generating superior performance. Larger assets under management, despite much lower returns, result in managers within multi-fund companies earning higher monetary compensation from both management and incentive fees, especially in recently launched funds. 


\section{Appendix A: Relative fund value computation}

In this paper, I compute the relative fund value with respect to the initially issued hedge fund shares. New fund shares issued later on will have their own high-water marks that are different from the initial one. However, different equalization techniques are used by hedge funds to make sure that all investors pay incentive fees only on profits earned on their investment.

The cumulative return earned by a hedge fund $i$ from its origination up to the period $t$ $\left(C R_{i t}\right)$ is, first, computed as

$$
C R_{i t}=\prod_{\tau=1}^{\mathrm{t}}\left(1+r_{i \tau}\right)
$$

where $r_{i \tau}$ denotes the return earned by the fund $i$ during period $\tau$.

The high-water mark $\left(H W M_{i}\right)$ of each hedge fund is initially set to one. It is recomputed every January and does not change throughout the following year. If the cumulative return earned by December $\left(C R_{i D}\right)$ is higher than the current high-water mark, the new high-water mark is set to the level of the cumulative return; otherwise it stays unchanged.

$$
H W M_{i}^{\text {New }}=\left\{\begin{array}{l}
C R_{i D}, \text { if } C R_{i D}>H W M_{i}^{\text {Current }} \\
H W M_{i}^{\text {Current }}, \text { if } C R_{i D} \leq H W M_{i}^{\text {Current }}
\end{array}\right.
$$

The relative value of fund $i$ for period $t$ (Value $i t)$ is computed as the ratio of the cumulative return earned by the fund up to this period over the corresponding high-water mark.

$$
\text { Value }_{i t}=\frac{C R_{i t}}{H W M_{i t}}
$$




\section{Appendix B: Control variables for fund flow}

This section gives an overview of hedge fund flow-related explanatory variables. The results reported in Tables 9 and 10 include only those control variables that turn out to be significant in at least one of the regressions considered, or seem to be very important economically. The results do not change if all other control variables discussed in this section are included in the regressions, and none of the additional controls is significant.

The first column of Table A1 lists the control variables, and the second column of the table presents some comments and reviews the related literature. All average values and standard deviations are computed over 6 or 12 months after hedge fund origination, depending on the corresponding investigation period.

Two commonly used controls are omitted in the current analysis: fund closure to new investment and investment illiquidity. The first one is irrelevant for analyzing flows into new funds, since after origination all funds are open to the public. To measure investment illiquidity one would need a sufficiently long time series to be able to compute any measure of illiquidity (the simplest being the first order serial correlation of the returns), which does not exist for newly originated funds. 
Table A1. Control variables for fund flow

\begin{tabular}{ll}
\hline \hline Control Variables for New Fund Flows & Comments \\
\hline Average monthly return & Past performance is one of the key variables driving hedge fund flow. \\
& $\begin{array}{l}\text { Since newly originated hedge funds do not have any track record, I } \\
\text { use contemporaneous performance instead. }\end{array}$
\end{tabular}

Squared average monthly return The performance is positively but nonlinearly related to current flows. For example, Ding, Getmansky, Liang and Wermers (2009) argue that, in the absence of share restrictions, the flow-performance relation is convex, but it becomes concave in the presence of restrictions. Since the past performance of newly originated funds is not available, the squared contemporaneous performance is used instead.

\begin{tabular}{ll}
\hline Standard deviation of the monthly returns & $\begin{array}{l}\text { Ding, Getmansky, Liang and Wermers (2009) also control for the } \\
\text { standard deviation of the past returns. }\end{array}$
\end{tabular}

Average past returns of all funds, following the same style as the newly Getmansky (2005) shows that investors follow outperforming styles. originated fund, and their squared values

Average past returns of all existing hedge funds and their squared values The squared values allow controlling for nonlinearities.

Wang and Zheng (2008) document that, on the aggregate level, fund flow is positively related to the performance of the hedge fund industry as a whole.

\begin{tabular}{ll}
\hline Average past returns of the $S \& P 500$ index & This factor proxies for general market conditions. \\
\hline Internet bubble dummy & This dummy controls for possible regime shifts in the fund flow \\
& pattern during the Internet bubble (e.g., Fung, Hsieh, Naik and \\
Ramadorai (2008)).
\end{tabular}

Seasonal dummies for a year beginning (a year end), taking a value of one if the fund origination month lies during the first (last) quarter of a year

Cumming and Dai (2009) show that, because of the tax effects, investors are reluctant to invest in hedge funds during the later months in a year. This results in higher flows during earlier months and lower flows during later months.

Management and incentive fees; lockup and notice periods; fund average leverage

Hedge funds with higher managerial incentives seem to enjoy higher flows, whereas hedge funds with higher impediments to capital withdrawal (lockup and notice periods) seem to have lower flows (Agarwal, Daniel and Naik (2004)).

\begin{tabular}{|c|c|}
\hline $\begin{array}{l}\text { Reported assets under management as of } \\
\text { fund origination date in millions of US\$ }\end{array}$ & $\begin{array}{l}\text { Ding, Getmansky, Liang and Wermers (2009) show that hedge funds } \\
\text { that have larger assets on average experience higher flows. }\end{array}$ \\
\hline $\begin{array}{l}\text { Percentage of the total assets under } \\
\text { management invested within Directional, } \\
\text { Relative Value, and Event Driven styles. } \\
\text { (The Equity Long/Short share is omitted in } \\
\text { order to avoid multicollinearity of the } \\
\text { regressors) }\end{array}$ & $\begin{array}{l}\text { Ding, Getmansky, Liang and Wermers (2009) argue that funds } \\
\text { following different investment styles exhibit different average flows } \\
\text { and flow volatilities. }\end{array}$ \\
\hline Minimum investment level & $\begin{array}{l}\text { Fund flow can depend on the minimum investment level (Cumming } \\
\text { and Dai (2009)). }\end{array}$ \\
\hline $\begin{array}{l}\text { Share of hedge funds closed to new } \\
\text { investments within a company }\end{array}$ & $\begin{array}{l}\text { If some funds within a family are closed to investment, investors } \\
\text { willing to invest within the fund family have to allocate their capital } \\
\text { to open funds, including a newly originated one. }\end{array}$ \\
\hline
\end{tabular}




\section{Appendix C: Reconstruction of the pre-fee hedge fund returns}

This appendix describes the procedure used to calculate the pre-fee returns of hedge funds, using the post-fee reported returns. It is copied from the appendix to the paper "Recovering Delisting Returns of Hedge Funds," by Hodder, Jackwerth and Kolokolova (2010) verbatim. The notations and equation numbering are preserved as in the original paper.

An incentive fee is normally paid annually, but the reported monthly returns are adjusted for the accrued incentive fee during the year. In other words, the accrued incentive fee is deducted when calculating a hedge fund's reported Net Asset Value (NAV); but that accrued fee stays invested in the fund until year end. In most cases, the management fee is paid at the end of each month at 1/12 of the yearly rate. The management fee calculation uses NAV on the last day of each month before the deduction of that month's accrued incentive fee. The modification we made relative to Brooks, Clare, and Motson (2007) involves using the end of month (rather than beginning of month) NAV to calculate the management fee. That change was based on our review of several hedge-fund prospectuses that indicated that this was the typical procedure.

The figure below illustrates the transition from the pre-fee to post-fee NAV, where $\mathrm{NAV}(\mathrm{t})$ denotes the reported post-fee NAV at the end of period t. NAV $(\mathrm{t})^{*}$ denotes the associated pre-fee NAV at the end of period t.

The reported post-fee return captures the change of the reported NAV from NAV(1) to NAV(2), as indicated by the dash-dot line. The pre-fee return changes from the pre-fee $\mathrm{NAV}(1)^{*}$ less the management fee (that is, equivalent to the reported $\mathrm{NAV}(1)$ plus the incentive fee at time 1) to $\operatorname{NAV}(2)^{*}$. The reconstructed $\operatorname{NAV}(2)^{*}$ is the sum of the reported NAV(2), the accrued incentive fee at time 2, denoted as $\operatorname{IF}(2)$, and the management fee MF 
(2). The incentive fee base at each time is the difference between the NAV less the management fee and the high-water-mark (HWM).

Thus, the total gross return for the period $\left(1+R_{G R O S S_{t}}\right)$ can be expressed as follows:

$$
\begin{gathered}
1+R_{\text {GROSS }_{t}}=\frac{N A V(t)+I F(t)+M F(t)}{N A V(t-1)+I F(t-1)} \\
R_{\text {GROSS }_{t}}=\frac{N A V(t)-N A V(t-1)+M F(t)+I F(t)-I F(t-1)}{N A V(t-1)+I F(t-1)}
\end{gathered}
$$

If a hedge fund is above HWM at time $\mathrm{t}$ based on its post management fee $\mathrm{NAV}$, it will stay above HWM after paying the percentage incentive fee. Denoting the percentage incentive fee by IncentiveFee\%, we obtain:

$$
\max (0, N A V(t)-H W M)=(1-\text { IncentiveFee\% }) \cdot \max (0, N A V(t)-H W M)+I F(t),
$$

This leads to the following expression for the accrued incentive fee at time t:

$$
I F(t)=\max (0, N A V(t)-H W M) \cdot\left(\frac{1}{1-\text { IncentiveFee\% }}-1\right)
$$


Figure A1. Pre-fee vs. post-fee net asset value

The figure illustrates the transformation of the pre-fee returns into the post-fee returns. The horizontal axis indicates the time periods during which returns are accumulated. At the end of each period, a new net asset value (NAV) is computed. The NAVs are marked on the vertical axis. NAV(t) stands for the reported post-fee NAV at the end of period t. NAV(t)* stands for the associated pre-fee NAV at the same time. Solid black lines indicate the pre-fee NAV change within a given period. The dash-dotted line indicates the change in reported post-fee NAV within the same period. Reported NAV at the end of a period is obtained by subtracting the management fee $\operatorname{MF}(\mathrm{t})$ and the incentive fee $\operatorname{IF}(\mathrm{t})$ from the pre-fee NAV. The incentive fee is zero if the pre-fee NAV less the management fee is below the high-water mark HWM. Otherwise it is computed as a share of the difference between the pre-fee NAV less the management fee and the HWM.

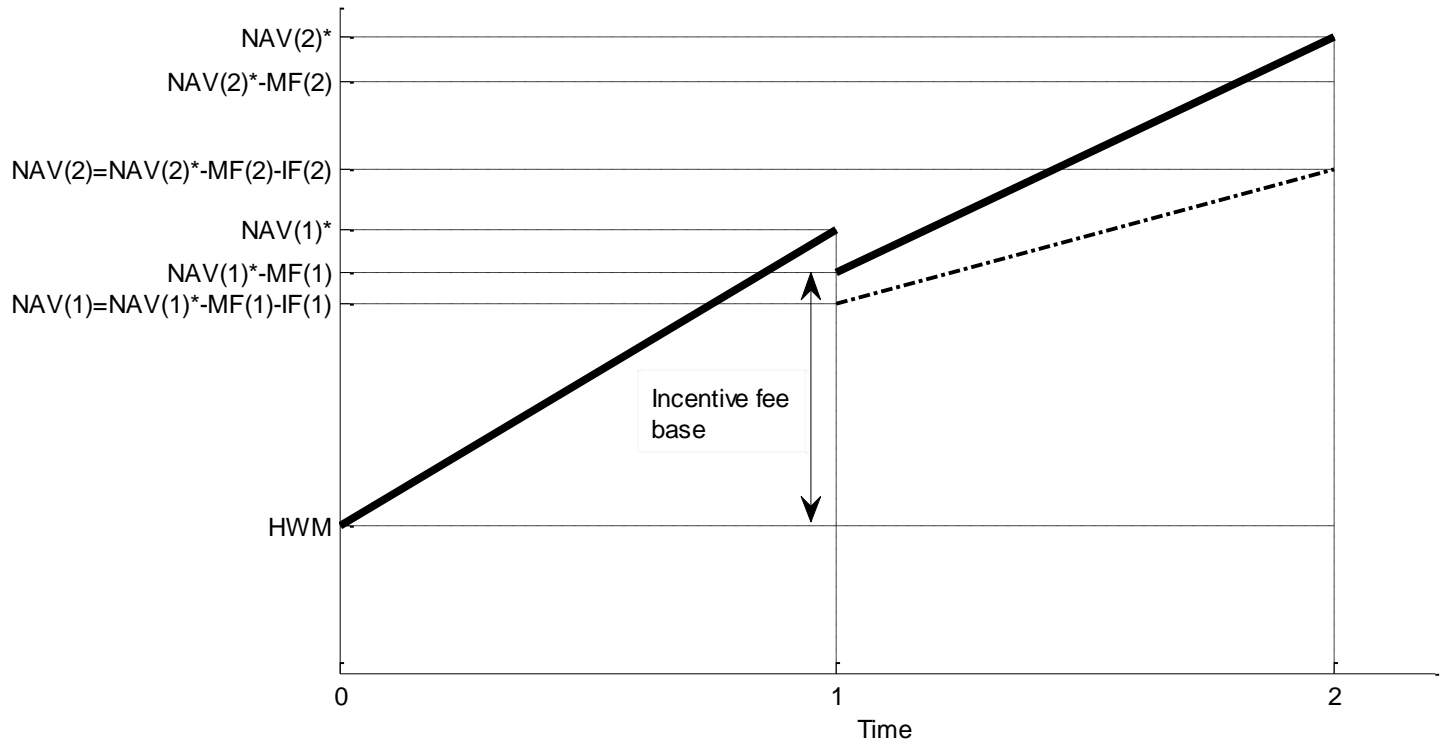


Similarly, the reported NAV plus the accrued incentive fee (if any) is a fraction of the total $\mathrm{NAV}^{*}$ equal to the total $\mathrm{NAV}^{*}$ minus the management fee. Thus, if the yearly management fee expressed in percentage terms is MgmtFee\%, we obtain:

$$
N A V(t)+M F(t)+I F(t) \cdot\left(1-\frac{M g m t F e e \%}{12}\right)=N A V(t)+I F(t)
$$

The management fee actually paid can be expressed as:

$$
M F(t)=N A V(t)+I F(t) \cdot\left(\frac{1}{1-\frac{M g m t F e e \%}{12}}-1\right)
$$

If, at year's end, NAV exceeds HWM, the new HWM for the next year is reset to the level of the post-fee NAV; and the accrued incentive fee is reset to zero. 


\section{Appendix D: Investment style classification according to the ALTVEST database}

The ALTVEST database divides all funds into three main styles: Directional, Relative Value, and Event Driven. In addition, it subdivides each style into smaller groups, which characterize more precisely hedge funds' investment strategies. In the current work, I consider Equity Long/Short funds not as a part of the Directional style, but as a separate group, since these funds represent the largest share of hedge funds reporting to the ALTVEST database. Below, the fund styles and their sub-categories are reported according to the ALTVEST classification.

Table A2. Hedge fund style classification according to the ALTVEST database

\begin{tabular}{ll}
\hline \hline 1. DIRECTIONAL & $\underline{\text { 2. RELATIVE VALUE }}$ \\
\hline Equity Long/Short & Capital Structure Arbitrage \\
Growth & \multicolumn{1}{c}{ Convertible Arbitrage } \\
Value & Other \\
Opportunistic & Equities Long/Short Equal Weighted \\
Short Selling & PIPES (private investment in public equities) \\
PIPES (private investment in public equities) & Fixed Income Arbitrage \\
Other & High Yield \\
Fixed Income & Mortgage Backed Securities (agencies) \\
High Yield & Mortgage Backed Securities (commercial) \\
Mortgage Backed Securities (agencies) & Corporate \\
Mortgage Backed Securities (commercial) & Sovereign (non-US) \\
Corporate & Treasuries \\
Sovereign (non-US) & Other \\
Treasuries & Index or Basis Trade Arbitrage \\
Other & Volatility Arbitrage \\
Global Macro & Closed End Fund Arbitrage \\
Currency & Other \\
Futures & \\
Mutual Fund Market Timing & 3. EVENT DRIVEN \\
Tactical Asset Allocation & Merger Arbitrage \\
Volatility Trading & Corporate Reorganization/Restructure/Spin-Offs \\
Other & Distressed Securities \\
& Special Situations \\
& Trade Claims \\
& Strategic Block/Activist Trading \\
\hline \hline & Other \\
\hline
\end{tabular}




\section{References}

Ackermann, C., McEnally, R., Ravenscraft, D., 1999. The performance of hedge funds: Risk, return, and incentives. Journal of Finance 54, 833-874.

Agarwal, V., Daniel, N.D., Naik, N.Y., 2004. Flows, performance, and managerial incentives in hedge funds. Working paper, Georgia State University.

Agarwal, V., Kale, J.R., 2007. On the relative performance of multi-strategy and funds of hedge funds. Journal of Investment Management 5, 41-63.

Amenc, N., Martellini, L., Vaissie, M., 2003. Indexing hedge fund indexes. Working paper, EDHEC Risk and Asset Management Research Centre.

Boyson, N.M., 2008. The impact of hedge fund family membership on performance and market share. Journal of Financial Transformation 25, 123-129.

Brooks, C., Clare, A., Motson, N., 2008. The gross truth about hedge fund performance and risk: The impact of incentive fees. Journal of Financial Transformation 24, 33-42.

Brown, S.J., Goetzmann, W.N., Park, J., 2001. Careers and survival: Competition and risk in the hedge fund and CTA industry. Journal of Finance 56, 1869-1886.

Chen, A.S., Cheng, L.Y., Cheng, K.F., Chih, S.W., 2010. Earnings management, market discounts and the performance of private equity placements. Journal of Banking and Finance 34, 1922-1932.

Chen, H.C., Lai, C.W., 2010. Reputation stretching in mutual fund starts. Journal of Banking and Finance 34, 193-207.

Chevalier, J., Ellison, G., 1997. Risk taking by mutual funds as a response to incentives. Journal of Political Economy 105, 1167-1200.

Cumming, D.J., Dai, N., 2009. Capital flows and hedge fund regulation. Journal of Empirical Legal Studies 6, 848-873. 
Cummins, D.J., Weissa, M.A., Xieb, X., Zi, H., 2010. Economies of scope in financial services: A DEA efficiency analysis of the US insurance industry. Journal of Banking and Finance 34, 1525-1539.

Ding, B., Getmansky, M., Liang, B., Wermers, R.R., 2009. Share restrictions and investor flows in the hedge fund industry. Working paper, University of Massachusetts at Amherst.

Fung, W., Hsieh, D.A., 2004. Hedge fund benchmarks: A risk-based approach. Financial Analysts Journal 60, 65-80.

Fung, W., Hsieh, D.A., Naik, N.Y., Ramadorai, T., 2008. Hedge funds: Performance, risk and capital formation. Journal of Finance 63, 1777-1803.

Gaspar, J.M., Massa, M., Matos, P.P., 2006. Favoritism in mutual fund families? Evidence on strategic cross-fund subsidization. Journal of Finance 61, 73-104.

Getmansky, M., 2005. The life cycle of hedge funds: Fund flows, size and performance. Working paper, MIT Sloan School of Management.

Goetzmann, W.N., Ingersoll, J.E., Jr., Ross, S.A., 2003. High-water marks and hedge fund management contracts. Journal of Finance 58, 1685-1717.

Gregoriou, G.N., 2002. Hedge fund survival lifetimes. Journal of Asset Management 2, 237252.

Griffin, J.M., Xu, J., 2009. How smart are the smart guys? A unique view from hedge fund stock holdings. Review of Financial Studies 22, 2531-2570.

Guedj, I., Papastaikoudi, J., 2008. Can mutual fund families affect the performance of their funds? Working paper, University of Texas at Austin.

Hodder, J.E., Jackwerth, J.C., 2007. Incentive contracts and hedge fund management. Journal of Financial and Quantitative Analysis 42, 811-826. 
Hodder, J.E., Jackwerth, J.C., Kolokolova, O., 2010. Recovering delisting returns of hedge funds. Working paper, University of Konstanz.

Jobson, J.D., Korkie, B.M., 1981. Performance hypothesis testing with the Sharpe and Treynor measures. Journal of Finance 36, 889-908.

Khorana, A., Servaes, H., 1999. The determinants of mutual fund starts. The Review of Financial Studies 12, 1043-1074.

Liang, B., 2000. Hedge funds: The living and the dead. Journal of Financial and Quantitative Analysis 35, 309-326.

Lo, A.W., 2001. Risk management for hedge funds: Introduction and overview. Financial Analysts Journal 57, 16-33.

Lo, A.W., 2002. The statistics of Sharpe ratios. Financial Analysts Journal 58, 36-52.

Massa, M., 2003. How do family strategies affect fund performance? When performancemaximization is not the only game in town. Journal of Financial Economics 67, 249304.

Memmel, C., 2003. Performance hypothesis testing with the Sharpe ratio. Finance Letters 1, 21-23.

Nanda, V., Wang, Z.J., Zheng, L., 2004. Family values and the star phenomenon: Strategies of mutual fund families. The Review of Financial Studies 17, 667-698.

Park, H., 2006. Risk measures for hedge funds and a survival analysis. Working paper, University of Massachusetts.

Wang, A., Zheng, L., 2008. Aggregate hedge fund flows and asset returns. Working paper, University of California, Irvine.

Zhao, X., 2004. Why are some mutual funds closed to new investors? Journal of Banking and Finance 28, 1867-1887. 


\section{Table 1. Investment companies' composition}

This table reports the number of investment companies in the ALTVEST database controlling different numbers of hedge funds (from 1 to more than 10) as well as the percentage of such companies in the total number of companies considered in the study. It also reports the number and the share of hedge funds controlled by those companies.

\begin{tabular}{ccccc}
\hline $\begin{array}{c}\text { Funds per } \\
\text { company }\end{array}$ & \multicolumn{2}{c}{ Companies } & \multicolumn{2}{c}{ Controlled funds } \\
& $\#$ & $\%$ & $\#$ & $\%$ \\
\hline 1 & 1162 & 53.01 & 1162 & 23.85 \\
2 & 536 & 24.45 & 1072 & 22.00 \\
3 & 204 & 9.31 & 612 & 12.56 \\
4 & 95 & 4.33 & 380 & 7.80 \\
5 & 49 & 2.24 & 245 & 5.03 \\
6 & 43 & 1.96 & 258 & 5.29 \\
7 & 25 & 1.14 & 175 & 3.59 \\
8 & 15 & 0.68 & 120 & 2.46 \\
9 & 10 & 0.46 & 90 & 1.85 \\
10 or more & 53 & 2.42 & 759 & 15.58 \\
More than 1 & 1030 & 46.99 & 3711 & 76.15 \\
\hline Total & 2192 & 100.00 & 4873 & 100.00 \\
\hline \hline
\end{tabular}




\section{Table 2. Database sample statistics}

This table reports the average descriptive statistics of the monthly returns (expressed in \% per month) of individual hedge funds reporting to the ALTVEST database. It is based on individual funds reporting returns in US\$ between January 1994 and June 2006. The first two rows report the number of funds and the average life time in years of the funds. The last two rows report the average p-values of the Jarque-Bera test of return normality and shares of hedge funds, for which the Jarque-Bera test rejects the normality of returns at least at the $10 \%$ level. Descriptive statistics are reported for all hedge funds, as well as for hedge funds belonging to single-fund and multi-fund families.

\begin{tabular}{|c|c|c|c|c|c|c|c|c|c|}
\hline & \multicolumn{3}{|c|}{ All funds } & \multicolumn{3}{|c|}{ Single-fund families } & \multicolumn{3}{|c|}{ Multi-fund families } \\
\hline & All & Live & Dead & All & Live & Dead & All & Live & Dead \\
\hline Number of funds & 4873 & 2130 & 2743 & 1162 & 510 & 652 & 3711 & 1620 & 2091 \\
\hline Life time in years & 4.670 & 5.600 & 3.940 & 4.142 & 5.193 & 3.540 & 4.905 & 5.671 & 4.262 \\
\hline Mean & 1.050 & 1.130 & 1.000 & 1.428 & 1.269 & 1.519 & 0.950 & 1.079 & 0.841 \\
\hline Median & 0.900 & 1.010 & 0.820 & 1.127 & 1.099 & 1.142 & 0.821 & 0.981 & 0.686 \\
\hline STD & 4.360 & 3.580 & 4.980 & 5.717 & 4.238 & 6.564 & 4.066 & 3.363 & 4.656 \\
\hline Min & -9.650 & -8.270 & -10.720 & -11.086 & -9.245 & -12.140 & -9.291 & -7.853 & -10.498 \\
\hline Max & 13.050 & 11.930 & 13.920 & 17.139 & 13.913 & 18.986 & 12.461 & 11.248 & 13.481 \\
\hline Skewness & 0.090 & 0.160 & 0.030 & 0.189 & 0.224 & 0.169 & 0.076 & 0.142 & 0.021 \\
\hline Kurtosis & 5.290 & 5.380 & 5.220 & 5.025 & 5.161 & 4.947 & 5.409 & 5.451 & 5.375 \\
\hline Sharpe Ratio & 0.250 & 0.320 & 0.190 & 0.256 & 0.313 & 0.223 & 0.240 & 0.323 & 0.170 \\
\hline $\begin{array}{l}\text { 1st order serial } \\
\text { correlation }\end{array}$ & 0.098 & 0.110 & 0.090 & 0.078 & 0.087 & 0.073 & 0.104 & 0.114 & 0.096 \\
\hline $\begin{array}{l}\text { Average p-value of } \\
\text { the JB-test }\end{array}$ & 0.100 & 0.111 & 0.092 & 0.110 & 0.129 & 0.098 & 0.097 & 0.107 & 0.090 \\
\hline $\begin{array}{l}\text { JB-test (share of funds } \\
\text { with p-value below } \\
10 \% \text { ) }\end{array}$ & 0.767 & 0.747 & 0.781 & 0.748 & 0.702 & 0.774 & 0.773 & 0.759 & 0.783 \\
\hline
\end{tabular}




\section{Table 3. Investment companies' composition by fund styles}

This table reports the composition of investment companies used in the current study with respect to fund styles. It reports the number of companies in which the most frequently used fund style is Equity Long/Short (ELS), Directional, Relative Value, Event Driven, or Multi-Strategy. The most frequently used style is defined as the style followed by the majority of funds within the company. The average share of funds with the most frequent style within a company is reported in the last column.

\begin{tabular}{|c|c|c|c|c|c|c|c|c|c|c|c|}
\hline \multirow{3}{*}{$\begin{array}{l}\text { Funds per } \\
\text { company }\end{array}$} & \multicolumn{10}{|c|}{ Companies in which the most frequent style is } & \multirow{3}{*}{$\begin{array}{c}\% \text { of funds with } \\
\text { the most } \\
\text { frequent style }\end{array}$} \\
\hline & \multicolumn{2}{|c|}{ ELS } & \multicolumn{2}{|c|}{ Directional } & \multicolumn{2}{|c|}{ Relative value } & \multicolumn{2}{|c|}{ Event driven } & \multicolumn{2}{|c|}{ Multi strategy } & \\
\hline & \# & $\%$ & \# & $\%$ & \# & $\%$ & \# & $\%$ & \# & $\%$ & \\
\hline 1 & 559 & 48.11 & 229 & 19.71 & 185 & 15.92 & 149 & 12.82 & 40 & 3.44 & 100.00 \\
\hline 2 & 260 & 48.51 & 78 & 14.55 & 94 & 17.54 & 88 & 16.42 & 16 & 2.99 & 92.02 \\
\hline 3 & 100 & 49.02 & 42 & 20.59 & 29 & 14.22 & 27 & 13.24 & 6 & 2.94 & 87.68 \\
\hline 4 & 52 & 54.74 & 20 & 21.05 & 15 & 15.79 & 6 & 6.32 & 2 & 2.11 & 87.41 \\
\hline 5 & 24 & 48.98 & 10 & 20.41 & 6 & 12.24 & 7 & 14.29 & 2 & 4.08 & 82.24 \\
\hline 6 & 23 & 53.49 & 11 & 25.58 & 7 & 16.28 & 2 & 4.65 & 0 & 0.00 & 84.65 \\
\hline 7 & 7 & 28.00 & 4 & 16.00 & 10 & 40.00 & 4 & 16.00 & 0 & 0.00 & 82.57 \\
\hline 8 & 8 & 53.33 & 2 & 13.33 & 5 & 33.33 & 0 & 0.00 & 0 & 0.00 & 83.09 \\
\hline 9 & 3 & 30.00 & 2 & 20.00 & 3 & 30.00 & 2 & 20.00 & 0 & 0.00 & 76.03 \\
\hline 10 or more & 32 & 60.38 & 6 & 11.32 & 10 & 18.87 & 4 & 7.55 & 1 & 1.89 & 70.87 \\
\hline More than 1 & 509 & 49.42 & 175 & 16.99 & 179 & 17.38 & 140 & 13.59 & 27 & 2.62 & 89.44 \\
\hline Total & 1068 & 48.72 & 404 & 18.43 & 364 & 16.61 & 289 & 13.18 & 67 & 3.06 & 94.99 \\
\hline
\end{tabular}


Table 4. Sample statistics of monthly fund flow

This table reports the sample statistics of monthly fund flows to all funds, as well as to subgroups of funds belonging to multi-fund and single-fund families. Panels A1 and A2 report statistics of absolute monthly flows. Panels B1 and B2 report statistics of percentage monthly flows. Panels A1 and B1 are based on flows to all funds and all dates. Panels A2 and B2 are based on flows during the first 6 months after funds' origination. Absolute fund flow for month $t$ is measured as the total change in the assets under management in millions US\$ $(A u M)$ during this month, adjusted for this month's return: $A b s F l o w_{t}=A u M_{t}-A u M_{t-l}\left(1+r_{t}\right)$. Percentage flow is a ratio of the absolute flow to the $A u M$ as of the end of the previous months:

RelFlow $_{t}=\left[A u M_{t}-A u M_{t-1}\left(1+r_{t}\right)\right] / A u M_{t-1}$.

\begin{tabular}{|c|c|c|c|c|c|c|c|c|c|}
\hline & \multicolumn{3}{|c|}{ All funds } & \multicolumn{3}{|c|}{ Single-fund families } & \multicolumn{3}{|c|}{ Multi-fund families } \\
\hline & All & Live & Dead & All & Live & Dead & All & Live & Dead \\
\hline & \multicolumn{9}{|c|}{$\begin{array}{l}\text { Panel A1: } \\
\text { flow in US\$ million, all funds }\end{array}$} \\
\hline Mean & 0.953 & 1.429 & 0.578 & 0.619 & 1.027 & 0.360 & 1.055 & 1.535 & 0.654 \\
\hline Median & 0.543 & 0.844 & 0.308 & 0.307 & 0.569 & 0.140 & 0.616 & 0.916 & 0.366 \\
\hline STD & 4.380 & 5.314 & 3.647 & 2.650 & 3.263 & 2.261 & 4.912 & 5.852 & 4.126 \\
\hline Minimum & -12.235 & -14.526 & -10.438 & -6.747 & -7.921 & -6.002 & -13.922 & -16.256 & -11.970 \\
\hline Maximum & 14.471 & 18.277 & 11.485 & 9.264 & 12.135 & 7.442 & 16.072 & 19.886 & 12.882 \\
\hline
\end{tabular}

Panel A2:

Absolute monthly flow in US\$ million, new funds, 6 months after origination

\begin{tabular}{lccccccccc}
\hline Mean & 1.284 & 1.728 & 0.935 & 0.711 & 1.038 & 0.503 & 1.460 & 1.908 & 1.085 \\
Median & 0.929 & 1.291 & 0.645 & 0.547 & 0.808 & 0.381 & 1.047 & 1.418 & 0.735 \\
STD & 2.045 & 2.310 & 1.837 & 1.103 & 1.307 & 0.974 & 2.334 & 2.572 & 2.135 \\
Minimum & -0.722 & -0.503 & -0.895 & -0.402 & -0.204 & -0.528 & -0.821 & -0.581 & -1.021 \\
Maximum & 4.115 & 4.966 & 3.446 & 2.242 & 2.913 & 1.816 & 4.690 & 5.504 & 4.009 \\
\hline
\end{tabular}

Panel B1:

Percentage monthly flow, all funds

\begin{tabular}{lccccccccc}
\hline Mean & 0.021 & 0.028 & 0.015 & 0.026 & 0.027 & 0.023 & 0.020 & 0.028 & 0.013 \\
Median & 0.010 & 0.013 & 0.007 & 0.011 & 0.009 & 0.011 & 0.009 & 0.014 & 0.006 \\
STD & 0.114 & 0.114 & 0.113 & 0.101 & 0.093 & 0.106 & 0.118 & 0.120 & 0.116 \\
Minimum & -0.307 & -0.320 & -0.300 & -0.214 & -0.201 & -0.225 & -0.336 & -0.350 & -0.326 \\
Maximum & 0.374 & 0.409 & 0.348 & 0.351 & 0.377 & 0.335 & 0.381 & 0.417 & 0.352 \\
\hline
\end{tabular}

Panel B2:

Percentage monthly flow, new funds, 6 months after origination

\begin{tabular}{lccccccccc}
\hline Mean & 0.057 & 0.069 & 0.049 & 0.050 & 0.054 & 0.047 & 0.060 & 0.072 & 0.049 \\
Median & 0.039 & 0.047 & 0.034 & 0.034 & 0.037 & 0.031 & 0.041 & 0.049 & 0.034 \\
STD & 0.099 & 0.103 & 0.095 & 0.092 & 0.093 & 0.092 & 0.101 & 0.106 & 0.096 \\
Minimum & -0.038 & -0.028 & -0.046 & -0.042 & -0.036 & -0.046 & -0.037 & -0.026 & -0.047 \\
Maximum & 0.191 & 0.210 & 0.176 & 0.176 & 0.181 & 0.171 & 0.196 & 0.217 & 0.177 \\
\hline \hline
\end{tabular}


Table 5. Determinants of hedge fund liquidation

This table reports the estimation results for the logit model of hedge fund liquidation. The sample includes those funds that are removed from the live database within each multi-fund company between June 1994 and June 2006, and those funds within the same company that are in operation on the date of the removal. The dependent variables corresponding to the removed funds take a value of one; the dependent variables corresponding to the surviving funds take a value of zero. The monthly observations (0s and $1 \mathrm{~s})$ are pooled together for all funds at all months considered. The first specification relates the drop probability to the absolute hedge fund characteristics. Average returns (expressed in \% per month) and their standard deviations are computed during the half-year prior to fund liquidation. The second specification is augmented by the factors' values relative to the company average. *, **, and $* * *$ indicate significance at the $10 \%, 5 \%$, and $1 \%$ levels, respectively.

\begin{tabular}{|c|c|c|c|c|c|}
\hline \multirow{2}{*}{\multicolumn{2}{|c|}{ Variable }} & \multicolumn{2}{|c|}{1} & \multicolumn{2}{|c|}{2} \\
\hline & & Coefficient & z-statistic & Coefficient & z-statistic \\
\hline \multicolumn{2}{|c|}{ Constant } & -42.799 & -1.341 & $-84.202 * *$ & -1.975 \\
\hline \multicolumn{2}{|c|}{ Average fund return (\%) } & $-0.053 * *$ & -1.966 & -0.006 & -0.155 \\
\hline \multicolumn{2}{|c|}{ Return standard deviation (\%) } & 0.019 & 1.411 & 0.004 & 0.221 \\
\hline \multicolumn{2}{|c|}{ Value relative to the HWM } & -0.268 & -0.761 & 0.244 & 0.537 \\
\hline \multicolumn{2}{|c|}{ Log AuM } & $-0.197 * * *$ & -5.686 & -0.012 & -0.260 \\
\hline \multicolumn{2}{|c|}{ Percentage flow } & $-1.945 * * *$ & -3.328 & $-1.641 * * *$ & -2.817 \\
\hline \multicolumn{2}{|c|}{ Management fee } & -0.085 & -1.057 & -0.043 & -0.534 \\
\hline \multicolumn{2}{|c|}{ Incentive fee } & -0.005 & -0.542 & 0.001 & 0.043 \\
\hline \multicolumn{2}{|c|}{ Notice period } & 0.000 & 0.012 & 0.001 & 0.297 \\
\hline \multicolumn{2}{|c|}{ Lockup period } & 0.009 & 0.084 & -0.033 & -0.223 \\
\hline \multicolumn{2}{|c|}{ Average leverage } & -0.003 & -0.347 & -0.002 & -0.177 \\
\hline \multicolumn{2}{|c|}{ Fund starting date } & 0.022 & 1.368 & $0.042 * *$ & 1.972 \\
\hline \multirow{2}{*}{\multicolumn{2}{|c|}{$\begin{array}{l}\text { Number of existing funds } \\
\text { Average fund return (\%) }\end{array}$}} & $-0.240 * * *$ & -9.307 & $-0.344 * * *$ & -11.037 \\
\hline & & & & $-0.143 * *$ & -2.299 \\
\hline \multirow{10}{*}{ 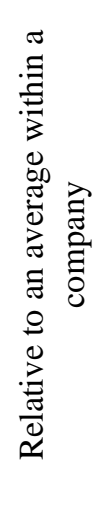 } & Return standard deviation & & & 0.048 & 1.547 \\
\hline & Value relative to the HWM & & & $-2.258 * * *$ & -2.768 \\
\hline & $\log \mathrm{AuM}$ & & & $-0.630 * * *$ & -7.893 \\
\hline & Percentage flow & & & -0.161 & -1.431 \\
\hline & Management fee & & & $-0.263 * *$ & -2.435 \\
\hline & Incentive fee & & & -0.012 & -0.565 \\
\hline & Notice period & & & $-0.014 * *$ & -2.040 \\
\hline & Lockup period & & & 0.143 & 0.593 \\
\hline & Average leverage & & & 0.000 & 0.022 \\
\hline & Fund starting date & & & $-0.094 * * *$ & -2.739 \\
\hline \multicolumn{2}{|c|}{ McFadden R-squared } & \multicolumn{2}{|c|}{0.125} & \multicolumn{2}{|c|}{0.191} \\
\hline \multicolumn{2}{|c|}{ Estrella R-squared } & \multicolumn{2}{|c|}{0.136} & \multicolumn{2}{|c|}{0.210} \\
\hline \multicolumn{2}{|c|}{ Log-Likelihood } & \multicolumn{2}{|c|}{-939.952} & \multicolumn{2}{|c|}{-868.878} \\
\hline \multicolumn{2}{|c|}{ Number of observations } & \multicolumn{2}{|c|}{1951} & \multicolumn{2}{|c|}{1951} \\
\hline \multicolumn{2}{|c|}{ Number of 0's, number 1's } & \multicolumn{2}{|c|}{1484,467} & & 4,467 \\
\hline
\end{tabular}




\section{Table 6. Determinants of hedge fund origination}

This table reports the estimation results for the logit model of hedge fund origination. The estimation is based on all fund families operating hedge funds launched between June 1994 and June 2006. The dependent variable takes a value of one if in a given month in a given family a new fund is opened, and zero otherwise. The monthly observations ( $0 \mathrm{~s}$ and $1 \mathrm{~s})$ are pooled together from all fund families. Those explanatory variables that are averages of some characteristics are computed over a six-month interval prior to the date of interest. Family_Return is the average monthly return (in \%) earned by the existing funds within the family during the half year prior to the origination of a new fund. NFunds is the number of funds existing in the family on the starting date of a new fund. TotalAuM is the natural logarithm of the last half year's average total assets under management of the existing funds in the family. The liquidation dummy $\left(D^{L i q}\right)$ takes a value of one if, within a year before or after a new fund's opening, any other fund was liquidated within the company. Other explanatory variables are contemporaneous with respect to the dependent variable start/no start of a new fund. *,**, and *** indicate significance at the $10 \%, 5 \%$, and $1 \%$ levels, respectively.

\begin{tabular}{lcc}
\hline \hline Variable & Coefficient & z-statistic \\
\hline Constant & $-5.280^{* * *}$ & -61.346 \\
\hline Family Related Variables & & \\
\hline Family_Return & $0.019^{* * *}$ & 3.742 \\
Nfunds & $0.140^{* * *}$ & 15.590 \\
TotalAuM & $0.135^{* * *}$ & 9.078 \\
$D^{\text {Liq }}$ & $0.148^{* *}$ & 2.520 \\
\hline Origination Controls & & \\
\hline Return standard deviation of existing funds in the family (\%) & $0.051^{* * *}$ & 6.073 \\
Dummy: average management fee below industry median & $-0.168^{* * *}$ & -3.418 \\
Dummy: average incentive fee below industry median & $-0.119^{*}$ & -1.815 \\
Dummy: average notice period below industry median & $0.091^{*}$ & 1.808 \\
Average hedge fund industry return & 0.035 & 0.944 \\
S\&P 500 index return & $0.037^{*}$ & 1.914 \\
\hline McFadden R-squared & 0.043 & \\
Estrella R-squared & 0.010 & \\
Log-Likelihood & -8725.8 & \\
Number of observations & 125872 & \\
Number of 0's, number 1's & 124145,1727 & \\
\hline \hline
\end{tabular}




\section{Table 7. Pre- and post-launching portfolio statistics}

This table reports the sample statistics of returns (expressed in \% per month) of two sets of portfolios: prelaunch and post-launch portfolios. Each set contains a families-based portfolio (consisting of hedge funds belonging to families launching new funds), and a random portfolio (consisting of randomly chosen funds during the same period). The pre-launch families-based portfolios include all funds within fund-families that exist 6 (12) months before additional funds within these families are launched. The post-launch families-based portfolios use funds that exist in families before the launching of new funds, but these funds are included in the portfolio for 6 (12) months after the new fund is launched.

\begin{tabular}{|c|c|c|c|c|c|c|c|c|}
\hline & \multicolumn{4}{|c|}{6 months } & \multicolumn{4}{|c|}{12 months } \\
\hline & \multicolumn{2}{|c|}{ Pre-launch } & \multicolumn{2}{|c|}{ Post-launch } & \multicolumn{2}{|c|}{ Pre-launch } & \multicolumn{2}{|c|}{ Post-launch } \\
\hline & $\begin{array}{c}\text { Families } \\
\text { based } \\
\text { (1) }\end{array}$ & $\begin{array}{l}\text { Random } \\
\text { (2) }\end{array}$ & $\begin{array}{c}\text { Families } \\
\text { based } \\
\text { (1) }\end{array}$ & $\begin{array}{c}\text { Random } \\
\text { (2) }\end{array}$ & $\begin{array}{c}\text { Families } \\
\text { based } \\
\text { (1) }\end{array}$ & $\begin{array}{c}\text { Random } \\
\text { (2) }\end{array}$ & $\begin{array}{c}\text { Families } \\
\text { based } \\
\text { (1) }\end{array}$ & $\begin{array}{c}\text { Random } \\
\text { (2) }\end{array}$ \\
\hline Mean & 1.246 & 1.087 & 1.049 & 1.097 & 1.160 & 1.103 & 0.958 & 1.035 \\
\hline Median & 1.111 & 1.238 & 1.058 & 1.163 & 1.030 & 1.260 & 1.017 & 1.143 \\
\hline Standard deviation & 2.016 & 2.037 & 2.185 & 1.960 & 1.871 & 1.908 & 2.127 & 1.972 \\
\hline Minimum & -4.584 & -6.399 & -7.222 & -6.842 & -4.767 & -6.834 & -7.652 & -7.243 \\
\hline Maximum & 10.073 & 7.836 & 10.160 & 7.777 & 8.344 & 6.992 & 8.798 & 7.680 \\
\hline Skewness & 0.917 & 0.051 & 0.413 & -0.140 & 0.499 & -0.201 & -0.013 & -0.309 \\
\hline Kurtosis & 7.055 & 4.337 & 6.277 & 4.739 & 4.943 & 4.610 & 5.762 & 5.199 \\
\hline Sharpe Ratio & 0.460 & 0.377 & 0.334 & 0.397 & 0.450 & 0.411 & 0.300 & 0.363 \\
\hline $\begin{array}{l}\text { p-value mean } \\
\text { difference }\end{array}$ & 0.010 & & 0.561 & & 0.227 & & 0.245 & \\
\hline $\mathrm{p}$-value $\mathrm{SR}(1)<\mathrm{SR}(2)$ & 0.008 & & 0.966 & & 0.076 & & 0.982 & \\
\hline
\end{tabular}




\section{Table 8. Performance of hypothetical long-short portfolios}

This table reports the estimation results for the regression of portfolios' returns (in \% per month) against the Fung and Hsieh (2004) seven-factor model. The portfolios are hypothetical. They long funds that belong to families that will launch a new fund in 6 (12) months (pre-launch) or that have launched a new fund 6 (12) months earlier (post-launch), and short the same number of randomly chosen funds. The newly launched funds are not used while constructing the portfolios. The standard errors are adjusted for heteroscedasticity and serial correlation, using the Newey-West correction with 12 lags. *,**, and *** indicate significance at the 10\%, 5\%, and $1 \%$ level, respectively.

\begin{tabular}{llllllllll}
\hline \hline & \multicolumn{4}{c}{6 months } & \multicolumn{5}{c}{12 months } \\
& \multicolumn{2}{c}{ Pre-launch } & \multicolumn{2}{c}{ Post-launch } & \multicolumn{2}{c}{ Pre-launch } & \multicolumn{2}{c}{ Post-launch } \\
Variable & Coef. & t-stat & Coef. & t-stat & Coef. & t-stat & Coef. & t-stat \\
\hline Alpha (\%) & $0.199 * * *$ & 4.442 & 0.007 & 0.123 & $0.095^{*}$ & 1.967 & -0.087 & -1.408 \\
Return on the S\&P 500 & & & & & & & & \\
index & 0.324 & 1.198 & 0.282 & 0.855 & $0.543^{* *}$ & 2.009 & -0.268 & -0.817 \\
Small Cap - Large Cap & -0.214 & -1.164 & -0.455 & -1.285 & -0.001 & -0.006 & 0.064 & 0.268 \\
Change10YTY & 0.382 & 1.085 & 0.688 & 1.075 & 0.057 & 0.125 & 0.805 & 1.443 \\
ChangeSpreadBaa & $-0.071^{* * *}$ & -4.596 & -0.023 & -0.903 & $-0.041^{* *}$ & -2.169 & -0.007 & -0.321 \\
PTFS_Bond & -0.001 & -0.023 & 0.037 & 0.688 & -0.022 & -1.063 & 0.015 & 0.311 \\
PTFS_Currency & $-0.425^{*}$ & -1.805 & -0.806 & -1.616 & 0.042 & 0.230 & -0.108 & -0.313 \\
PTFS_Commodity & -0.729 & -1.247 & $-1.267 *$ & -1.703 & -0.280 & -0.652 & -0.695 & -1.295 \\
\hline Adjusted R-squared & 0.176 & & 0.085 & & 0.126 & & 0.042 & \\
\hline \hline
\end{tabular}




\section{Table 9. Flow to new hedge funds within families}

This table reports the estimation results for the regression of average monthly percentage and absolute flows to newly originated funds within already existing families during the first 6 and 12 months after their start. Funds not reporting the assets under management for the complete 6- or 12-month periods are excluded from the analysis. Absolute fund flow for month $t$ is measured as a total change in the assets under management $(A u M)$ during this month adjusted for this month's return: $A b s F l o w_{t}=A u M_{t}-A u M_{t-1}\left(1+r_{t}\right)$. Percentage flow is a ratio of the absolute flow to the $A u M$ as of the end of the previous month:

RelFlow $_{t}=\left[A u M_{t}-A u M_{t-1}\left(1+r_{t}\right)\right] / A u M_{t-1}$. Family_Return is the average monthly return (in \%) earned by the existing funds within the family $6(12)$ months prior to the origination of a new fund. *,**, and *** indicate significance at the $10 \%, 5 \%$, and $1 \%$ level, respectively.

\begin{tabular}{|c|c|c|c|c|c|c|c|c|}
\hline & \multicolumn{4}{|c|}{ Absolute monthly flow } & \multicolumn{4}{|c|}{ Percentage monthly flow } \\
\hline & \multicolumn{2}{|c|}{6 months } & \multicolumn{2}{|c|}{12 months } & \multicolumn{2}{|c|}{6 months } & \multicolumn{2}{|c|}{12 months } \\
\hline & Coef. & t-stat & Coef. & t-stat & Coef. & t-stat & Coef. & t-stat \\
\hline Constant & 0.57 & 1.568 & 0.251 & 0.72 & $0.100 * * *$ & 3.616 & $0.062 * * *$ & 3.293 \\
\hline \multicolumn{9}{|l|}{ Family Related Variables } \\
\hline Family_Return & $0.166^{* * *}$ & 4.77 & $0.216 * * *$ & 4.614 & $0.009 * * *$ & 3.808 & $0.008 * * *$ & 3.297 \\
\hline Mean family return STD & $-0.076 * * *$ & -3.719 & $-0.089 * * *$ & -3.334 & $-0.004 * * *$ & -2.964 & -0.002 & -1.374 \\
\hline Cross-fund return STD & -0.074 & -1.36 & -0.003 & -0.051 & -0.001 & -0.374 & -0.002 & -0.940 \\
\hline \# funds, same style & -0.109 & -1.648 & -0.039 & -0.64 & 0.000 & 0.005 & 0.000 & 0.101 \\
\hline \# funds, other styles & 0.107 & 1.621 & 0.055 & 0.816 & -0.002 & -0.459 & $-0.004 *$ & -1.850 \\
\hline Total AuM, same style & $2.008 * * *$ & 4.589 & $1.596 * * *$ & 4.123 & 0.016 & 1.147 & 0.009 & 0.670 \\
\hline Total AuM, other styles & 0.12 & 0.472 & 0.135 & 0.683 & -0.002 & -0.332 & 0.007 & 0.886 \\
\hline Family Age & 0.057 & 1.295 & 0.03 & 0.717 & 0.002 & 0.579 & 0.001 & 0.331 \\
\hline Liquidation dummy & -0.258 & -0.719 & -0.463 & -1.344 & $-0.050 * * *$ & -3.115 & $-0.025 * *$ & -2.057 \\
\hline \multicolumn{9}{|c|}{ Individual Hedge Fund Related Variables } \\
\hline Mean return & $0.104 * * *$ & 2.743 & $0.133 * * *$ & 3.206 & $0.006 * * *$ & 2.569 & $0.005^{* * *}$ & 2.812 \\
\hline STD return & $-0.040 *$ & -1.754 & $-0.053 * *$ & -2.006 & 0.001 & 0.698 & 0.001 & 0.326 \\
\hline Management fee & -0.021 & -0.469 & -0.035 & -0.83 & -0.004 & -1.553 & $-0.004 * * *$ & -2.787 \\
\hline Incentive fee & 0.018 & 1.412 & $0.044 * * *$ & 3.852 & $0.002 *$ & 1.8 & $0.002 * * *$ & 3.309 \\
\hline Lockup period & $0.631 * * *$ & 2.839 & 0.189 & 0.956 & 0.011 & 1.016 & 0.008 & 1.130 \\
\hline Notice period & 0.003 & 0.751 & 0.005 & 1.262 & 0.000 & 1.357 & 0.000 & -0.152 \\
\hline Leverage & $-0.007 * *$ & -2.239 & $-0.006^{* *}$ & -2.062 & 0.000 & -0.113 & 0.000 & -0.010 \\
\hline \multicolumn{9}{|l|}{ Macro Variables } \\
\hline Mean past style return & 0.151 & 1.54 & 0.127 & 1.069 & 0.003 & 0.451 & -0.004 & -0.677 \\
\hline $\begin{array}{l}\text { Mean past S\&P500 } \\
\text { return }\end{array}$ & -0.011 & -0.195 & -0.015 & -0.191 & -0.005 & -1.086 & $-0.007 *$ & -1.954 \\
\hline Mean past all HFs return & $-0.415^{* *}$ & -2.545 & $-0.600 * * *$ & -2.999 & -0.012 & -0.931 & 0.000 & -0.036 \\
\hline Total flow to all HFs & $0.208 * * *$ & 3.782 & $0.308 * * *$ & 4.561 & $0.006^{*}$ & 1.916 & $0.010^{* * *}$ & 3.279 \\
\hline Internet Bubble dummy & -0.157 & -0.825 & -0.115 & -0.68 & -0.006 & -0.373 & 0.005 & 0.431 \\
\hline Adjusted R-squared & 0.114 & & 0.130 & & 0.021 & & 0.033 & \\
\hline Number of observations & 1938 & & 1831 & & 1938 & & 1831 & \\
\hline
\end{tabular}




\section{Table 10. Flow to all new hedge funds}

This table reports the estimation results for the regression of average monthly flows to newly originated funds 6 and 12 months after their start. Funds not reporting the assets under management for the complete 6- or 12month periods are excluded from the analysis. Absolute fund flow for month $t$ is measured as a total change in the assets under management $(A u M)$ during this month adjusted for this month's return: AbsFlow $w_{t}=A u M_{t}-$ $A u M_{t-1}\left(1+r_{t}\right)$. Percentage flow is the ratio of the absolute flow to the $A u M$ as of the end of the previous month: RelFlow $_{t}=\left[A u M_{t}-A u M_{t-1}\left(1+r_{t}\right)\right] / A u M_{t-1}$. $D_{\text {Family }}$ indicates a new fund launched within an already existing family; $D^{+}$Family indicates a new fund launched within a family with above median performance over the last half year, and $D_{\text {Family }}^{-}$indicates a new fund launched after a short period of superior performance within a family, which does not perform well persistently. $*$, **, and *** indicate significance at the 10\%, 5\%, and $1 \%$ level respectively.

\begin{tabular}{|c|c|c|c|c|c|c|c|c|}
\hline & \multicolumn{4}{|c|}{ Absolute monthly flows } & \multicolumn{4}{|c|}{ Percentage monthly flow } \\
\hline & \multicolumn{2}{|c|}{6 months } & \multicolumn{2}{|c|}{12 months } & \multicolumn{2}{|c|}{6 months } & \multicolumn{2}{|c|}{12 months } \\
\hline & Coef. & t-stat & Coef. & t-stat & Coef. & t-stat & Coef. & t-stat \\
\hline Constant & -0.203 & -0.903 & -0.392 & -1.530 & $0.052 * * *$ & 2.971 & $0.039 * * *$ & 2.893 \\
\hline \multicolumn{9}{|l|}{ Family Dummies } \\
\hline$D_{\text {Family }}$ & $0.340 * * *$ & 2.669 & $0.329 * *$ & 2.468 & $0.026 * * *$ & 2.744 & $0.013^{*}$ & 1.766 \\
\hline$D_{\text {Family }}^{+}$ & $0.984 * * *$ & 5.400 & $0.745 * * *$ & 4.334 & $0.029 * *$ & 2.537 & $0.019 * *$ & 2.225 \\
\hline$D_{\text {Family }}^{-}$ & -0.279 & -0.646 & -0.495 & -1.217 & 0.000 & 0.015 & -0.021 & -1.141 \\
\hline \multicolumn{9}{|c|}{ Individual Hedge Fund Related Variables } \\
\hline Mean return & $0.083 * * *$ & 3.614 & $0.124 * * *$ & 4.704 & $0.007 * * *$ & 4.479 & $0.007 * * *$ & 3.541 \\
\hline STD return & $-0.037 * * *$ & -4.277 & $-0.045^{* * *}$ & -5.117 & 0.000 & 0.242 & $-0.002 * *$ & -2.470 \\
\hline Management fee & 0.042 & 1.145 & 0.034 & 0.865 & -0.002 & -0.764 & -0.001 & -0.350 \\
\hline Incentive fee & $0.020 * * *$ & 2.627 & $0.029 * * *$ & 3.784 & $0.001 *$ & 1.685 & $0.001 * * *$ & 3.003 \\
\hline Lockup period & 0.200 & 1.451 & -0.040 & -0.323 & 0.009 & 1.485 & 0.007 & 1.483 \\
\hline Notice period & $0.009 * * *$ & 2.764 & $0.008 * * *$ & 2.665 & $0.000 * *$ & 2.192 & 0.000 & 0.387 \\
\hline Leverage & -0.001 & -0.393 & 0.000 & -0.059 & 0.000 & 0.007 & 0.000 & -0.274 \\
\hline Minimum investment & $0.000 *$ & -1.658 & $0.000^{*}$ & -1.687 & 0.000 & -0.062 & 0.000 & -0.673 \\
\hline Directional style & $0.346^{*}$ & 1.690 & 0.042 & 0.223 & $0.025 * *$ & 2.023 & 0.013 & 1.520 \\
\hline Relative Value style & $0.437 * *$ & 2.500 & $0.438 * *$ & 2.458 & 0.018 & 1.495 & 0.008 & 0.881 \\
\hline Event Driven style & -0.204 & -1.196 & -0.099 & -0.579 & $-0.021 *$ & -1.844 & 0.003 & 0.284 \\
\hline \multicolumn{9}{|l|}{ Macro Variables } \\
\hline Mean style return & 0.120 & 1.118 & 0.232 & 1.220 & $0.022 * * *$ & 2.971 & $0.017 *$ & 1.759 \\
\hline Mean style return squared & -0.004 & -0.398 & -0.022 & -0.823 & $-0.002 * *$ & -2.091 & -0.002 & -1.173 \\
\hline Mean S\&P500 return & 0.003 & 0.059 & 0.014 & 0.222 & $-0.005^{*}$ & -1.683 & $-0.007 * *$ & -2.127 \\
\hline Mean return of all HFs & $-0.327 * * *$ & -2.621 & $-0.338 * *$ & -1.966 & $-0.027 * * *$ & -2.757 & -0.012 & -1.465 \\
\hline Total flow to all HFs & $0.229 * * *$ & 6.423 & $0.317 * * *$ & 7.173 & $0.007 * * *$ & 3.940 & $0.009 * * *$ & 5.268 \\
\hline Internet Bubble dummy & $-0.190 *$ & -1.662 & -0.203 & -1.563 & -0.004 & -0.413 & 0.004 & 0.515 \\
\hline Adjusted R-squared & 0.060 & & 0.071 & & 0.031 & & 0.032 & \\
\hline Number of observations & 3819 & & 3648 & & 3819 & & 3648 & \\
\hline
\end{tabular}




\section{Table 11. Managers' income from management and incentive fees}

This table reports average monthly dollar management fees and accrued incentive fees earned by hedge funds during the first year after origination, during the third year of funds' life, and in the last year prior to liquidation. The fees are in millions of US dollars. The fees are reported for all funds, as well as for funds belonging to single-fund and multi-fund families. Post-launch fees are reported for live and dead funds separately. Preliquidation fees are reported only for dead funds. The last column reports the p-values for the null hypothesis of the average fee equality between hedge funds launched within single-fund and multi-fund families. For postlaunch fees, the comparison is made for all funds; for pre-liquidation fees, the comparison is made for dead funds only.

\begin{tabular}{|c|c|c|c|c|c|c|c|c|c|c|}
\hline & \multicolumn{3}{|c|}{ All funds } & \multicolumn{3}{|c|}{ Single-fund families } & \multicolumn{3}{|c|}{ Multi-fund families } & \multirow[t]{2}{*}{$\mathrm{p}$-value } \\
\hline & All & Live & Dead & All & Live & Dead & All & Live & Dead & \\
\hline \multicolumn{11}{|c|}{ Average over one year after fund start } \\
\hline Management fee & 0.045 & 0.060 & 0.032 & 0.026 & 0.040 & 0.017 & 0.050 & 0.066 & 0.037 & 0.001 \\
\hline Accrued incentive fee & 0.752 & 0.950 & 0.609 & 0.534 & 0.427 & 0.595 & 0.820 & 1.087 & 0.614 & 0.026 \\
\hline \multicolumn{11}{|c|}{ Average over the third year of fund life } \\
\hline Management fee & 0.085 & 0.097 & 0.073 & 0.049 & 0.052 & 0.046 & 0.094 & 0.108 & 0.080 & 0.005 \\
\hline Accrued incentive fee & 2.372 & 2.382 & 2.362 & 2.017 & 1.547 & 2.464 & 2.462 & 2.583 & 2.336 & 0.262 \\
\hline \multicolumn{11}{|c|}{ Average over one year prior to fund liquidation } \\
\hline Management fee & & & 0.086 & & & 0.051 & & & 0.098 & 0.001 \\
\hline Accrued incentive fee & & & 4.658 & & & 6.888 & & & 3.875 & 0.228 \\
\hline
\end{tabular}


Table 12. Determinants of managers' income: Returns and assets under management

This table reports average monthly returns (in \% per month), average monthly excess returns over a hedge-fund industry average (in \% per month), and average monthly assets under management (in million US\$) of hedge funds one year after origination, during the third year of funds' life, and one year prior to liquidation. The values are reported for all funds, as well as for funds belonging to single-fund and multi-fund families. The post-launch values are reported for live and dead funds separately. The pre-liquidation values are reported only for dead funds. The last column reports the p-values for the null hypothesis of the equality between the average returns/assets under management of hedge funds launched within single-fund and multi-fund families. For postlaunch values, the comparison is made for all funds; for pre-liquidation values, the comparison is made for dead funds only.

\begin{tabular}{|c|c|c|c|c|c|c|c|c|c|c|}
\hline & \multicolumn{3}{|c|}{ All funds } & \multicolumn{3}{|c|}{ Single-fund families } & \multicolumn{3}{|c|}{ Multi-fund families } & \multirow[t]{2}{*}{ p-value } \\
\hline & All & Live & Dead & All & Live & Dead & All & Live & Dead & \\
\hline \multicolumn{11}{|c|}{ Average over one year after fund start } \\
\hline Return $(\%)$ & 1.477 & 1.426 & 1.514 & 1.825 & 1.529 & 1.995 & 1.369 & 1.399 & 1.345 & 0.000 \\
\hline $\begin{array}{l}\text { Excess return over the HF } \\
\text { industry average }(\%)\end{array}$ & 0.394 & 0.431 & 0.367 & 0.746 & 0.583 & 0.839 & 0.284 & 0.391 & 0.202 & 0.000 \\
\hline Assets under management & 38.133 & 50.223 & 29.442 & 19.743 & 26.446 & 15.906 & 43.873 & 56.432 & 34.198 & 0.000 \\
\hline \multicolumn{11}{|c|}{ Average over the third year of fund life } \\
\hline Return $(\%)$ & 1.260 & 1.193 & 1.329 & 1.438 & 1.263 & 1.604 & 1.215 & 1.176 & 1.256 & 0.014 \\
\hline $\begin{array}{l}\text { Excess return over the HF } \\
\text { industry average }(\%)\end{array}$ & -0.029 & 0.049 & -0.108 & 0.149 & 0.186 & 0.115 & -0.074 & 0.016 & -0.167 & 0.035 \\
\hline Assets under management & 73.428 & 75.468 & 71.343 & 48.859 & 46.217 & 51.370 & 79.623 & 82.513 & 76.613 & 0.030 \\
\hline \multicolumn{11}{|c|}{ Average over one year prior to fund liquidation } \\
\hline Return (\%) & & & 0.430 & & & 1.002 & & & 0.230 & 0.000 \\
\hline $\begin{array}{l}\text { Excess return over the HF } \\
\text { industry average }(\%)\end{array}$ & & & -0.585 & & & -0.053 & & & -0.772 & 0.000 \\
\hline Assets under management & & & 78.354 & & & 49.264 & & & 88.566 & 0.001 \\
\hline
\end{tabular}

